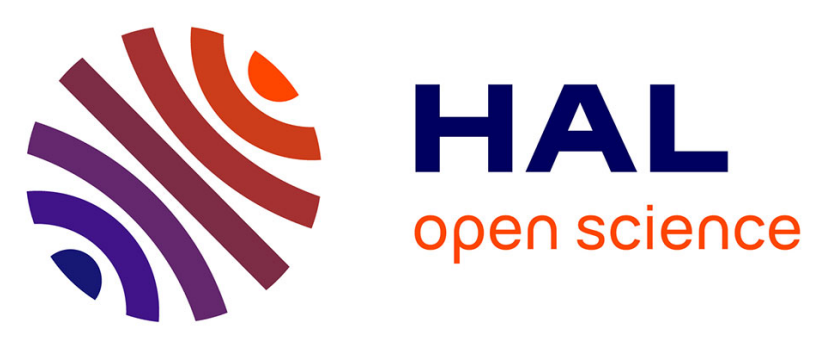

\title{
Understanding volcanic systems and their dynamics combining field and physical volcanology with petrology studies
}

\author{
Raffaello Cioni, Marco Pistolesi, Massimo Pompilio, Bruno Scaillet
}

\section{- To cite this version:}

Raffaello Cioni, Marco Pistolesi, Massimo Pompilio, Bruno Scaillet. Understanding volcanic systems and their dynamics combining field and physical volcanology with petrology studies. Forecasting and Planning for Volcanic Hazards, Risks, and Disasters, Chapitre 7, Elsevier, pp.285-328, 2021, Chapter 7 - Understanding volcanic systems and their dynamics combining field and physical volcanology with petrology studies, 10.1016/B978-0-12-818082-2.00007-X . insu-02962335

\section{HAL Id: insu-02962335}

\section{https://hal-insu.archives-ouvertes.fr/insu-02962335}

Submitted on 9 Oct 2020

HAL is a multi-disciplinary open access archive for the deposit and dissemination of scientific research documents, whether they are published or not. The documents may come from teaching and research institutions in France or abroad, or from public or private research centers.
L'archive ouverte pluridisciplinaire HAL, est destinée au dépôt et à la diffusion de documents scientifiques de niveau recherche, publiés ou non, émanant des établissements d'enseignement et de recherche français ou étrangers, des laboratoires publics ou privés. 


\section{Understanding volcanic systems and their dynamics combining}

\section{field and physical volcanology with petrology studies}

3
Raffaello Cioni ${ }^{1}$, Marco Pistolesi ${ }^{2}$, Massimo Pompilio ${ }^{3}$, Bruno Scaillet ${ }^{4}$

${ }^{1}$ Dipartimento Scienze della Terra, Università di Firenze, Italy

2 Dipartimento Scienze della Terra, Università di Pisa, Italy

${ }^{3}$ Istituto Nazionale di Geofisica e Vulcanologia, Sezione di Pisa, Italy

${ }^{4}$ Institut des Sciences de la Terre d'Orléans, Orléans, France

\section{Abstract}

Hazard assessment and definition of the eruptive scenarios at active volcanoes are mostly based on the elaboration of a large set of information collected with different disciplines and multiple analytical approaches. We discuss here how the reconstruction of the main processes acting at a volcano during its life should be based on the direct knowledge of its activity and products, in the view that each volcano is characterized by its own «personality». Comparison with analogue volcanoes can add further important information on the expected variability of the different processes, but this should never substitute specific data collection at the volcano of interest. Field volcanology and petrology studies are the base for collecting large datasets on past, recent and on-going activity and products. Based on these data, intensive and extensive physical parameters which control the dynamics of the activity can then be derived through focused physical volcanology investigations. Experimental petrology on the products of well-characterized 
24 eruptions finally returns a set of additional physical and compositional parameters that heavily 25 contribute to enlarge our knowledge of the activity and evolution of a given volcano.

Volcanic activity is the result of a complex series of processes at different scales involving magma dynamics in the mantle-crust system. The type of erupted products, and the style of eruptive activity, are deeply controlled by the different processes of magma evolution in time and

31 space. The different stages and the modalities of magma accumulation and transfer at shallow

32 depths in the crust, heat and mass exchange with the surrounding host rocks or from the magma 33 source, and consequent magma crystallization, evolution and eventually degassing, are crucial in 34 controlling the variability of eruptive styles.

Understanding the main characteristics of volcanic activity in terms of style, timing, physical

36 processes and evolution is the key for developing a comprehensive, quantitative assessment of

37 volcanic hazards and for the definition of the range of expected eruptive scenarios at an active 38 volcano. In order to get this complex picture, the volcanic system should be considered in its 39 entireness as a complex system in which the processes controlling the different parts concur to 40 regulate its general behavior. For this reason, various approaches should be combined in order to 41 unravel the complex interplay among the zone of storage, the shallow plumbing system connecting 42 a volcanic system to the surface, the volcanic edifice and the variability of the deposits emplaced 43 during eruptions. The knowledge of location, internal geometry, and history of a volcanic system 44 thus represents the basis for the interpretation of the modalities of magma eruption to the surface. 45 Therefore, when dealing with these aspects, an exhaustive study of the whole volcano should be 46 initially planned, with the goal of being largely representative of the different processes which 
47 regulated its history. Field studies, physical characterization and petrological investigations on 48 ongoing eruptions or on past volcanic products can be a powerful and effective tool to investigate

49 the main features of the volcanic system and its variation in time and in space (Fig. 1). These data 50 offer the frame for the interpretation of the geophysical and geochemical signals collected at 51 selected volcanic areas, during quiescent periods, episodes of unrest or eruptions. They serve to 52 define a reliable model for the interpretation of the modalities of reactivation and for the expected 53 variability of eruption styles at active volcanoes.

54 When studying the products of the past activity of a volcano, collection of data of very 55 different types (age, composition, sedimentological features of the deposits, etc.) can be generally 56 carried out at two different scales:

57 - At the scale of the whole volcano history, by collecting data on the different products 58 emplaced through time, in order to gain insights into the temporal evolution of the volcano and its 59 deep and shallow plumbing systems;

- At the scale of single eruptions, by looking at the products of selected events to reconstruct

61 in detail the evolution of magma reservoir(s), the processes of reactivation and the dynamics of 62 the eruption.

63 In this chapter we will discuss the different types of approach suggested for defining the 64 evolution of a volcanic system and its general eruptive behavior, using information derived from 65 field volcanology, physical characterization of eruptions and petrology studies. We will discuss 66 first the rationale for the two different scales of observations described above, and the set of field 67 studies and physical data needed to collect different sets of information. This part will be 68 preliminary to the presentation and discussion of the methods used in modern petrology aimed at 69 enlarging our knowledge of volcanic system evolution and behavior. The main objective of this 
chapter is to illustrate how the direct knowledge of a single volcanic system is fundamental for

71 understanding its activity and evolution so as to reach a robust assessment of volcanic hazards.

72 The use of data from "analogue" volcanoes worldwide can be useful to derive a first order range

73 of expected styles of activity at a given volcano, but should never substitute specific, focussed

74 research on the volcano of interest.

recorded in the physico-chemical features of the erupted products and in the sedimentological and volcanological characteristics of its erupted products. For this reason, the study of the deposits of

80 past eruptions is a pre-requisite for gaining an in depth understanding of the internal structure of

81 the volcanic system. Eruptive history can be reconstructed through collection of a complex set of

82 information on the products of past eruptions, the time-progression of activity, and the phases of

83 morphological and structural evolution of the volcanic edifice. The basic dataset is composed by

84 geological, volcanological, geochemical and petrological data. The reconstruction of the tectonic

85 setting also allows to frame the volcanic activity in a general picture explaining its evolution with

86 time, the composition of involved magmas and the frequency and type of activity (Crisp, 1984;

87 Wilson, 2007).

\section{Geological mapping and stratigraphic studies}

Geological mapping of a volcanic area gives the fundamental framework for interpreting the

90 temporal evolution of the activity and the most important changes in the structure of a volcanic

91 system (Groppelli and Viereck-Goette, 2010). This type of studies should be still considered as a

92 forefront topic, although in the past decade very few resources (both human and economic) have 
93 been dedicated to this activity. Moreover, although geological maps exist for various active,

94 quiescent or inactive volcanoes, many of them have been traced in the past using mainly a

95 petrological approach or old volcanological concepts (i.e. in many maps pyroclastic products are

96 often described and grouped under the general, lithological term of "tuffs", without further

97 information useful to derive their genetic or depositional processes). A complete revision of these

98 maps should be still considered as a priority. For this reason, the production of geological maps in

99 volcanic areas should be addressed toward the compilation of real "volcanological" maps, in which

100 deposits and products are presented and described under a volcanological perspective, with legends

101 and stratigraphic or structural schemes which maximize information on the volcanic evolution.

102 Introduction of unconformity bounded stratigraphic units (UBSU) derived from sequence

103 stratigraphy has been for example proposed at Italian volcanoes by several authors to summarize

104 the volcano evolution, although lithostratigraphic units remain the best way to report and describe

105 the geology of a volcanic area (Groppelli and Viereck-Goette, 2010 and refs. therein). Structural

106 geology data should always complement volcanological maps, as they represent an indispensable

107 piece of information, especially at active volcanoes, to understand their past dynamics as well the

108 expected behavior during future episodes of unrest (Acocella 2007, 2014; Azzaro et al., 2012;

109 Cembrano and Lara, 2009; Tibaldi et al., 2003). Mapping of volcanic areas strongly relies on the

110 reconstruction of a detailed reference stratigraphic sequence, which is a complex and time-

111 consuming task to achieve (Fig. 2; Marti et al., 2018, and refs. therein). This can be acquired only

112 through an extended, detailed field survey of the entire pile of emplaced deposits. In large volcanic

113 areas, with activity from different centers (at local or regional scale), the identification of clearly

114 defined stratigraphic markers in the succession is a primary task, which can be used to correlate

115 the activity of the different volcanic centers and to define the temporal evolution of the activity. In 
116 some cases, stratigraphic data can be integrated with those derived from distal and ultra-distal sites

117 (both marine, lacustrine and terrestrial) where tephra beds are recollected, identified and dated

118 (Pyle et al., 2006; Matthews et al., 2012; Engwell et al., 2014). Only in a few cases, such as at 119 frequently erupting volcanoes in inhabited areas and with a long-lasting written tradition, 120 eyewitnesses' accounts are useful to reconstruct the most recent period of activity and to fill in 121 possible gaps in the stratigraphic sequence related to small-scale eruptions with scarce deposition 122 and/or preservation. The preservation potential for the deposits of past eruptions in fact strongly 123 varies as a function of the general dispersal, thickness and grain-size of the deposits of each 124 eruption (roughly correlated to the intensity and magnitude; Pyle, 2015), and on climate, that may 125 enhance rapid weathering and erosion also of very recent deposits. Moreover, a volcanic area is a 126 highly dynamic morphological system in which short periods of deposition alternate with 127 prolonged periods of erosion and landscape reshaping (Collins and Dunne, 1986; Nemeth and 128 Cronin, 2007; Thouret, 1999). In many cases, the time for the latter is order of magnitudes longer 129 than that during which eruptions occur and products accumulate. These discontinuous dynamics 130 are also amplified by the large variability of frequency and magnitude (considered as proxies for 131 the volume of erupted products) of the eruptions, with the largest, low-frequency events being 132 generally best recorded in the stratigraphic sequence and preserved also in distal sequences with 133 respect to the more frequent, smaller events, mostly dispersed in the proximal sectors of the 134 volcano. All these factors may result in a partial, incomplete geological record of the past activity 135 and need to be carefully evaluated when trying to reconstruct a detailed history of a volcanic 136 system (Brown et al., 2014; Newhall and Self, 1982).

137 Geochronological studies 
Radiometric dating of the deposits is an essential tool that should always accompany the

139 stratigraphic reconstruction, giving an absolute measure of the timing for the different processes

140 (e.g., eruptions, magma evolution, edifice building). A detailed, high resolution dataset (both in

141 terms of precision of age determination and number of dated events) is vital, as it can reveal

142 different trends in the activity, such as temporal clustering of eruptions, or variability of frequency

143 with time (Fig. 3). Geochronological data are strongly unevenly distributed between the different

144 volcanoes worldwide, and totally lacking at many important active volcanic systems, especially in

145 remote areas (Simkin et al., 1981). In most cases, available absolute ages derive from

146 inhomogeneous datasets obtained with different techniques and at different laboratories, often

147 resulting in discordant results. In addition, many available geochronological datasets suffer from

148 a lack of systematic sampling approach with respect to the eruptive history. Time-related

149 reconstructions at the scale of the entire volcanic system should be planned together with

150 geological mapping and stratigraphic investigations, in order to systematize data collection.

\section{Physical characterization of eruptions}

152 Physical characterization of volcanic eruptions should strongly rely on the basic geologic

153 information at the scale of the volcano. These studies involve detailed stratigraphic reconstructions

154 of the deposits of single eruptions, as well as their areal dispersal and the derivation of the main

155 physical parameters which can help eruption classification and understanding of the main

156 processes acting during eruptions (Bonadonna et al., 2015, 2016; Carey and Sparks, 1986; Mastin

157 et al., 2009). At the scale of the whole volcanic system, deposit studies are fundamental to assess

158 the variability of the eruption scenarios shown by the volcanic system in its history (Table 1; Cioni

159 et al., 2008). Together with the information from absolute dating and the time evolution of the

160 volcanic activity (both at short and long time-scales), these combined datasets represent the basic 
161 source to prepare informed and reliable hazard maps and emergency plans. In the recent years, the

162 definition of event trees for the expected evolution of the activity at a given volcano (Newhall and

163 Hoblitt, 2002) has become a common practice in volcanology. This type of theoretical scheme,

164 which summarizes the expected progression of events before a volcanic crisis, is more robust if

165 elaborated with a case-by-case approach, using all the geological and volcanological information

166 available at a given volcanic system (Neri et al., 2008; Marti et al., 2008).

\section{Petrology and geochemistry of erupted products}

Petrology and geochemistry of erupted products represent other important aspects to be

169 explored in order to get a complete view of a volcanic system and of its evolution. To depict

170 exhaustively magmatic evolution with time, these data should derive from a systematic collection

171 deeply based on the volcanological and geochronological framework built for that system. This is

172 not the case for data currently available at many volcanoes worldwide, that often suffer problems

173 of underrating of specific phases of activity. Petrological and geochemical studies, coupled with

174 experimental constraints (see sections below), give first order information about the depth of the

175 different parts of the magma storage system and its possible migration with time (e.g., Gardner et

176 al., 1995; Scaillet et al., 2008). They can also allow to define the conditions of magma stalling,

177 crystallization and evolution at depth, or they can inform about the modalities of pre- and syn-

178 eruptive magma ascent to surface (Blundy and Cashman, 2008; Rutherford, 2008). The

179 reconstruction of the evolution of a volcanic system gives the possibility to understand the overall

180 compositional variability shown by the products and to frame their temporal progression. In many

181 cases, it is possible to define cycles of volcano evolution associated to differences in the

182 composition of the erupted magma (Fig. 4). Important information on the depth of the different

183 portions of the volcanic system and on the interaction between magma and host rocks can also be 
184 derived from the petro-mineralogical study of lithic fragments ejected during the different 185 explosive events (Di Rocco et al., 2012; Fulignati et al., 2004). Similarly, deep-derived nodules 186 are often found in lavas or pyroclastics, opening a window onto source mechanisms of magma 187 generation, migration and fragmentation at a specific volcano. All these aspects will be discussed 188 in detail in a following section.

\section{Studying single-eruption sequences}

Important data on eruption processes and eruptive dynamics can be extracted from the

192 detailed study of the products erupted during single eruptions. In this case, the indispensable

193 dataset is represented by the accurate description of the sequence of eruptive products, acquired

194 through detailed stratigraphic, sedimentological and laboratory analyses of the deposits. Different 195 problematics arise in the study of the products of effusive vs. explosive eruptions.

196 Effusive eruptions are generally characterized by the occurrence, often contemporaneous, of lava

197 emission and small-scale explosive activity. Unless in the presence of direct observations of the

198 eruption, the stratigraphic relationships between the products of these two types of activity are

199 often not simple to resolve in the field, due to different dispersal and, often, to the multi-vent 200 character of these eruptions. Sample collection from lava flows, lava flow fields or lava domes is 201 generally less problematic with respect to pyroclastic material due to the generally narrower, more 202 regular dispersal. However, while in pyroclastic products it is generally straightforward to 203 recognize directly in the field the sequence of deposition (and hence eruption) of the deposits, this 204 can be very difficult in complex, long-lasting, often multi-vent past effusive eruptions. Beside this, 205 samples representative of the entire course of the effusive activity can be very difficult to obtain, 206 as magma erupted during the first phases of an effusion can become rapidly inaccessible, unless 
they are preserved (and still recognizable) at specific locations in the flow, such as at the front or 208 along the lateral levees.

Explosive eruptions often result in a complex sequence of deposits, in terms of type (tephra 210 fall, pyroclastic density currents, etc.), dispersal and stratigraphic relationships. Detailed

211 stratigraphy is the first step to trace time and space evolutions of the different deposits, These

212 studies are also the base for the preparation of tephra dispersal maps (isopach, isopleth maps) for

213 the different deposits that can be used to define several extensive (e.g., volume and mass of erupted

214 magma, amount of xenolithic material) and intensive parameters (e.g., plume height, mass flow

215 rate, clast ejection velocity, velocity and dynamic pressure of pyroclastic density currents) of the 216 eruption (Carey and Sigurdsson, 1986; Cioni et al., 2000; Pistolesi et al., 2015, 2017; Todde et al.,

217 2017). The knowledge of all these parameters enables a parameterization of the different types of

218 eruptions which occurred during the life of a volcanic system, thus allowing to relate eruption

219 dynamics with the general features of the volcanic system (magma composition and rheology, 220 rates of magma feeding and evolution, depth and size of magma reservoirs). For an active volcano, 221 this dataset can be successfully used to the assess a range of representative eruption scenarios, to 222 understand its general style of activity (and time evolution) and to build an effective hazard 223 assessment framework (Tab. 1; Cioni et al., 2008).

\section{$224 \quad$ Sampling strategies for pyroclastic deposits}

225 The collection of a large set of representative samples for different types of explosive 226 eruptions commonly needs a combination of preparatory studies to be carried out (e.g., selection 227 of the outcrops, sampling strategy). The choice of sampling strategy should always be preceded 228 by a preliminary characterization of the stratigraphy, dispersal, thickness variation and volume of 229 the eruption (e.g., Fisher and Schmincke, 1984; Cas and Wright, 1987; Thordarson et al., 2009; 
230 Gurioli et al., 2015). Volcanic plumes which form during explosive eruptions are in fact complex

231 systems and their properties do not vary linearly with the main eruption parameters. The external

232 variables such as wind direction and velocity add further complexity to the tephra sedimentation

233 (i.e. clast-type distribution). Particularly when dealing with recent or ongoing eruptions, sampling

234 should be preceded by an accurate field analysis of the deposits. On this basis, the strategy should

235 consider deposit variability and key locations which synthesize the whole eruptive sequence. Once

236 defined the suitable outcrop(s), an inspection of the base-to-top variability is needed to assess syn-

237 eruptive wind direction or eruption intensity changes. In case of important lithologic and

238 sedimentologic vertical variability (e.g., grain-size, color, density/vesicularity, general

239 morphology, vesicle shape and crystallinity) at the outcrop scale, the identification of different

240 layers is needed prior to collection, eventually sampling each tephra layer at different equivalent

241 locations rather than collecting all samples at a single outcrop (Fig. 5). This is because

242 sedimentation from volcanic plumes is affected by clast size, shape and density (Bonadonna et al.,

243 1998; Pfeiffer et al., 2005; Barsotti et al., 2008; Eychenne et al., 2013), and thus single exposure

244 sampling may affect relative proportions within the deposit of the sampled material which can

245 vary with distance from the vent.

246 While the textural and sedimentological clast variability can be studied at a single outcrop, the

247 relative proportions between the different components of the deposit should be investigated across

248 the whole deposit dispersal by integrating outcrops and sampling at different distances from the

249 vent. Variability of juvenile clasts can be related to inhomogeneous magmatic sources

250 (mixing/mingling processes) or to different syn-eruptive conditions of degassing and

251 crystallization. Sampling is thus particularly crucial when dealing with petrological investigations,

252 which should ensure the representativeness of the collected juvenile fractions for analytical studies 
253 as well as low to absent alteration degree. In the presence of a large variability of juvenile clasts,

254 sampling should be followed by componentry analysis of the clasts population in order to obtain

255 homogenous sub-sets of samples before further analyses (e.g., sample grinding for powders, thin

256 sections). The accurate analysis of proximal deposits can reveal the presence of important,

257 although thin and often poorly dispersed, deposits related to the opening phases of the eruption.

258 The sampling and study of the products of these phases can give important insights into the

259 mechanisms triggering the eruption and accompanying the onset of magma ascent to the surface

260 (Cioni et al., 2000; Sulpizio et al., 2010), as well as the complex processes of magma-rock

261 interaction during the final upward migration of the feeder dyke (Pistolesi et al., 2015).

262 Componentry of pyroclastic deposits

263 Pyroclastic deposits are characterized by the presence of clasts derived from the

264 fragmentation of a range of products of different sources, which are distinguished as juvenile and

265 accessory, xenolithic material (Fisher and Schmincke, 1984). Juvenile material represents the

266 magma actively driving the eruption, and most of the petrologic studies are obviously performed

267 on this type of material. The detailed examination of the different types of clasts present in the

268 products of a pyroclastic eruptions can be an incredibly prolific source of information on the

269 different processes affecting magma during an eruption. Microanalytical and textural studies of

270 the fragments are useful to identify the final processes of magma ascent and have been largely

271 used also to indirectly derive the rates of magma ascent, degassing and crystallization (Cashman,

272 1992; Cashman and Blundy, 2000). Identification of juvenile clasts with different composition in

273 a same eruption, even at a same stratigraphic level or within a single clast, are fundamental to

274 characterize pre-eruptive states of the magma, the existence of compositional gradients in the

275 magma reservoir and the temporal sequence of magma extraction during an eruption. 
During eruption, or under pre-eruption conditions, changes in the final composition of the

277 melt phase can be induced by complex processes such as crystallization, assimilation of country

278 rocks, or mixing among different magmatic melts. Magma mixing is often suggested as one of the 279 most common triggers of eruptive activity (Sparks et al., 1978).

If juvenile material is the main, direct source of data about the state of the magma before an 281 eruption, accessory material (accidental or cognate clasts; Fisher and Schmincke, 1984) brings

282 precious information about rocks hosting the volcanic system (contact portions of the reservoir,

283 conduit, crater area) and all kinds of interaction between magma and the host rocks (metasomatic 284 and thermo-metamorphic rocks from the magma reservoir/host rock shell, different kinds of 285 magma cumulates). In case of large eruptions, the combined study of stratigraphy and 286 componentry of the deposits is also used to estimate the dimension of the eruptive magma 287 conduit/crater system and the timing for caldera collapse that may eventually occur.

\section{Internal variability in the products of an effusive eruption}

Differently from pyroclastic deposits, the products of effusive activity are almost completely

290 dominated by juvenile magma; mafic lavas are generally strongly homogeneous, mainly due to the

291 low viscosity (also after near complete degassing of the magma) that favors a rapid hybridization

292 of different melts in mixed systems or the rapid disappearance of internal compositional gradients.

293 In such cases, information of the interaction of the magma with different melts is only preserved

294 in the phenocryst population, that can give first-hand information on the physical and chemical

295 conditions of magma evolution. In particular cases, the low viscosity of mafic magmas can result

296 in high ascent rates to the surface, and the ensuing lava flows are characterized by the presence of

297 high-density, crystal-rich, mafic nodules of different size (from mm- up to dm-sized) that may give 298 information both on deep-seated crystallization processes or even on the mantle source. 
Effusive activity of silicic magmas, forming lava domes or poorly mobile flows (coulées,

300 tholoids, obsidian flows, etc.), often results in more heterogeneous products, as the high viscosity

301 of the melt-crystal system tends to preserve traces of any interaction of the magma with other melts

302 or rocks, and to show physical mingling instead of chemical hybridization between different

303 magmatic melts with contrasting rheological features. In this case, it is very common to observe a

304 variety of enclaves (Bacon, 1986) that reveal, with their composition and texture, the origin and 305 dynamics of mixing at depth.

\section{Petrological constraints to magma genesis and evolution}

The journey of magmas from the mantle source to the surface can be very complex owing to

309 the heterogeneity of the lithosphere and the variability of tectonic regime (Cashman et al., 2017;

310 Scandone et al., 2007). Direct evidence of the geometry and extension of volcanic plumbing

311 systems are mainly derived from geological investigations carried out on ancient dissected

312 volcanic centers or exhumed crustal sections. High resolution seismic profiles or crustal

313 tomography can also provide a variably detailed picture of the extension and complexities of the

314 plumbing system. These methods in most cases provide only a static representation of the spatial

315 complexity of the plumbing system and notwithstanding recent advances on 4D seismic

316 tomography, quite often fail in detailing the physico-chemical parameters at work. More generally,

317 geophysical information is restricted to eruptions that have occurred in the last decades (i.e.

318 accompanying the deployment of geophysical networks). Conversely, a basic assumption of

319 petrological investigations is that compositional and textural variability revealed by petrological

320 methods reflects changes in physical (e.g., pressure, temperature) and chemical (e.g. $\mathrm{fO}_{2}$ )

321 parameters during magma ascent, storage and eruption. 
Information on the pre-or syn-eruptive evolution of magmas is generally preserved in their

323 compositional and textural features. For example, crystals and melts provide information about

324 cooling, crystallization, contamination and mixing history, vesicles and melts on volatile content

325 and degassing dynamics.

326 Whatever the research approach used (at the scale of the entire volcano, or restricted to single

327 eruption sequences), petrological studies should be applied to the products in order to extract

328 information on the main processes that controlled magma genesis and evolution, as well as to

329 define the main compositional differences of the erupted products.

330 In general, key information about the magmatic system that petrology can provide include:

331 - The nature and the composition of the magma source;

332 - The physical and chemical conditions of magmatic processes;

333 - The dynamics of magmatic processes;

334 - The timescales for magma crystallization and degassing.

335 To obtain the above information, volcanologists collect petrological and textural data on

336 natural rocks and their components and interpret these data on the basis of experiments and 337 thermodynamic/ physical models.

\section{The nature and composition of the magma source}

Nature and composition of the magma source are mainly investigated via isotope

340 geochemistry on primitive melts and/or on deep-seated xenoliths entrained upward by the magma.

341 Texture and mineral assemblage of xenoliths, once modifications occurring during ascent are

342 filtered out, bear evidence of the nature of the source (Armienti et al., 2013, Corsaro et al., 2009b,

343 Pichavant et al., 2009, Wright \& Klein, 2006). By definition, primitive melts are close to the

344 composition of melts in equilibrium with the mantle mineralogy. Criteria for recognizing the 
345 attainment of the equilibrium are based on the $\mathrm{K}_{\mathrm{d}}$ of melt-olivine equilibria, assuming that olivine

346 with Fogo $_{90}$ is the fundamental component of a residual peridotite. Primitive melts are rare and

347 recognizable as melt inclusions (MIs) trapped in mafic minerals as olivine or pyroxene (Grove et 348 al., 2002; O'Hara \& Herzberg, 2002; Pichavant et al., 2002, 2011; Schiano, 2003; Asimow et al., 349 2004; Green et al., 2004; Smith \& Leeman, 2005; Streck et al., 2007).

350 In most central volcanoes, primitive melts reach the surface only if the characteristic time of 351 transport/ascent through the crust is short enough (highly buoyant magmas) that stopover, cooling 352 or crystallization in the crust are reduced and interaction or mixing with shallow residing magmas 353 is limited (Corsaro \& Pompilio 2004a; Coltelli et al. 2005; Kamenetsky et al. 2007).

354 At some volcanoes (e.g., Etna, Teide or Pantelleria) these conditions are more easily met 355 during flank eruptions, when feeder dykes bypass the central plumbing system. Radiogenic 356 isotopic ratios ( $\mathrm{Sr}, \mathrm{Nd}$ and $\mathrm{Pb}$ systematics) and ratios between stable isotopes of noble elements 357 (e.g. Helium) carry information on the geochemical evolution and modification of the source (e.g. 358 metasomatism) since these ratios are not modified during melting, crystallization or degassing 359 (Tonarini et al., 2001; Francalanci et al., 2004, 2007; Tommasini et al., 2007; Pietruszka et al., 360 2015; Corsaro \& Métrich, 2016; Di Renzo et al., 2018). The knowledge of the composition of 361 primitive magmas that feed crustal reservoirs and of their variability in time is crucial for 362 determining the compositional evolution of crustal reservoirs.

363 Defining physical and chemical parameters of magmatic processes

364 At almost every stage of magma migration through the crust, cooling and crystallization can 365 take place to some extent. If crystals are preserved in the erupted magma, the whole history can be 366 deciphered and physical and chemical parameters relevant to magmatic processes estimated 367 (Jerram et al., 2018). In the scientific literature of the last 40 years, thermodynamic modeling of 
368 phase equilibria between liquid, gas and solid phases has been largely employed to estimate 369 pressure and temperature at which magmatic processes occur (Ghiorso \& Sack, 1995; Ghiorso \& 370 Gualda, 2015; Gualda et al., 2012). This important advancement has been possible thanks to the 371 large improvement of microanalytical techniques, that allowed the accurate compositional and 372 textural analysis of single phases at a spatial resolution of few microns, and to a wealth of new 373 experiments on natural and synthetic materials allowing a fine tuning of general models, and their 374 application to the knowledge of the plumbing system of a single volcano.

375 A huge number of case-histories appearing in the scientific literature can be cited, however the 376 best and more accurate results are those derived from the study of the products of volcanoes that 377 erupted frequently or during long periods in the last decades (e.g., Etna, Kilauea, Stromboli, Piton 378 de la Fournaise, Mt. Saint Helens, Monserrat) or those for which detailed field studies allowed to 379 reconstruct with a good approximation single key eruptions (e.g., Vesuvius, Santorini) or a large 380 part of the eruptive history (Putirka, 1997; Corsaro \& Pompilio, 2004b; Del Carlo \& Pompilio, 381 2004; Corsaro et al., 2007, 2009a, 2012, 2014; Peltier et al., 2009; Mollo et al., 2015; Giacomoni 382 et al., 2016, Perinelli et al., 2016; Di Renzo et al., 2018). Pressure and temperature of magma 383 evolution often derive from accurate studies of fluid and MI, as testified by a huge literature 384 starting from the seminal work of Roedder (1979) up to the recent reviews of Kent (2008), Métrich 385 and Wallace (2008) and Moore (2008). In particular, MIs trapped in crystals in equilibrium with 386 the magma driving the eruption can preserve their history of crystallization, recording the temporal 387 variation of the composition and volatile content of magma and giving also the possibility to 388 measure the trapping temperature (Roedder, 1979; Lowenstern, 2001). Volatile content of MI has 389 been often used for estimating the minimum pressure of crystallization, assuming volatile 390 saturation in the melt, so allowing to reconstruct the possible geometry of a plumbing system (e.g., 
391 Pamucku et al., 2015; Métrich et al., 2010; Fig. 6). MI studies must be always accompanied by

392 detailed petrological investigations in order to shed light on the significance of the different hosting 393 phases, and on the possible post-entrapment changes of the melt by host crystallization, MI 394 maturation and degassing, or melt-crystal diffusion (Nielsen et al, 1998).

\section{Dynamics of magmatic processes}

Once assessed where the magma is stored within the crust, it is essential to understand what

397 happens within these stable or short-lived magmatic reservoirs, if some interaction occurs with the

398 host rocks, if and in which proportion magmas mix together or with assimilated crustal material, 399 and if liquid, solid or gas phases separate or accumulate.

400 Classical methods embrace compositional investigations on bulk rocks or on single phases, using 401 information derived from radiogenic isotopes and trace elements. Some examples include recent 402 eruptions or eruptive periods of well-known volcanoes (Pompilio et al., 2011; Meletlidis et al., 4032012 ; Troll et al., 2012; Marti et al., 2013; Longpré et al., 2014; Del Moro et al., 2015, Meletlidis 404 et al., 2015, Di Renzo et al., 2018). Textural analyses including both descriptive (e.g., habitus, 405 shape) and quantitative information derived from crystal or vesicle size distributions have been 406 also largely employed, in most of active volcanoes, thanks to the tremendous recent development 407 of image analysis techniques. A combined textural and compositional analysis of fine-grained 408 pyroclasts (ash and lapilli) can give clues on magmatic processes within the plumbing system, 409 such as crystallization and degassing (Hammer et al., 1999, 2000; Blundy and Cashman, 2001; 410 Taddeucci et al., 2004; Schiavi et al., 2006, 2010; D’Oriano et al., 2011; Pompilio et al., 2017).

411 A new original and promising approach at the scale of single crystals is the system analysis

412 (Fig. 7) introduced by Kahl et al. (2011). The basic assumption is that the growth of a sector of a 413 crystal records the crystallization process within a given magmatic environment. A magmatic 
414 environment (ME) can be generally defined as a portion of the magmatic plumbing system (not

415 only restricted to the magma reservoir) characterized by a distinctive set of intensive

416 thermodynamic variables (e.g., temperature, pressure, melt composition, water content, and

417 oxygen fugacity). Considering that crystal growth occurs sequentially from core to rim, it can be

418 assumed that the compositions at the rim record the latest magmatic environment while the inner

419 sectors record progressively older environments. Thus, the chemical stratigraphy recorded in the

420 compositional zoning patterns can be used to track the evolution of different magma batches

421 through distinct magmatic environments. However, the interpretation of the patterns of zoning

422 within crystals of the same eruption is not simple, but a system analysis plot (Fig. 7) can clarify

423 the relationships between diverse magmatic environments.

$424 \quad$ Timescales for magma crystallization and degassing

425 Most of intensive thermodynamic variables (e.g., pressure, temperature, volatile content and

426 composition) pertaining to magmatic environments are derived assuming equilibrium conditions

427 and ignoring the kinetics of the processes. In this way, the temporal information that can work as

428 "sync-signal" between petrology and other geophysical signals, is missing. Only in the last two

429 decades, the "re-discovery" of the kinetics of magmatic processes has allowed to obtain robust and

430 precise estimation of timescales, allowing correlation between different signals. Such new

431 petrological techniques include crystal and vesicle size distributions, multi-element diffusion

432 chronometry, and measurements of short-lived isotopes (Hawkesworth et al., 2004; Cooper and

433 Kent, 2014; Petrone et al., 2014).

434 Information on the kinetics of the crystallization or degassing derived by crystal or bubble size

435 distributions have been largely employed to obtain the timescales of storage and ascent of magmas.

436 After the precursory work of Marsh (1988), these techniques have been applied to several 
437 volcanoes with different compositions and mineral assemblages (Cashman and Marsh, 1988;

438 Mangan, 1990; Cashman, 1992; Hammer et al., 1999; Zieg \& Marsh, 2002; Taddeucci et al., 2004;

439 Zellemer et al., 2005; Higgins, 1996; 2006; Armienti, 2008; Salisbury et al., 2008; Higgins \&

440 Roberge, 2007; Morgan et al., 2007a; Proussevitch et al., 2007; Fornaciai et al., 2015; Jerram et

441 al., 2018). In order to recover accurate temporal information from a quantitative textural analysis

442 it is necessary to have a robust estimate of kinetic parameters such as growth and nucleation rates

443 and their relationships with pressure, temperature, undercooling and composition (Armienti,

444 2008). Similarly, the modeling of the diffusive modification of zoning profiles in mineral provides

445 information on the timescale of melt transfer through the plumbing system. For this reason,

446 diffusion modeling is being increasingly used to obtain timescales of individual magmatic

447 processes or sequences of processes. Early applications include the study of eruption of Vesuvius,

448 Santorini, Etna, Mount St. Helens, and most of them include correlation with geophysical signals

449 useful for volcano hazard monitoring (Zellmer et al., 1999, 2003, 2005; Morgan et al., 2007b; Kahl

450 et al., 2011, 2013, 2015, 2017; Charlier et al., 2012; Druitt et al., 2012; Marti et al., 2013;

451 Chamberlain et al., 2014; Albert et al., 2015, 2016).

\section{Experimental constraints on volcano evolution and eruption dynamics}

As explained above, the petrological study of erupted products can give invaluable 455 information about processes occurring at depth and about the nature of magmas involved in the 456 eruptive mechanisms. In order to correlate such an information with physical inferences made from 457 the study of volcanic deposits it is essential, however, that the petrological information is placed 458 into a robust and quantitative pressure-temperature framework. This is the reason for carrying out 459 experiments in the laboratory, whose prime aim is the replication of essential petrological 
460 attributes which are preserved by juvenile material ejected during the eruption, under carefully

461 controlled intensive parameters ( $\mathrm{P}, \mathrm{T}$, volatiles etc.). It is therefore vital that experimental efforts

462 come only when an in-depth field and petrological knowledge is available, so that the laboratory

463 work is performed on relevant and representative rock types and under naturally constrained

464 physical conditions.

465 Experiments that can be done are of various sort: (1) phase equilibria, (2) volatile solubilities,

466 (3) mixing/interaction experiments, (4) decompression experiments, and (5) measurements of

467 physical properties of rocks and magmas. All these experiments are done for durations which can

468 be very short compared to the timescales attending the construction of volcanic edifices: typically,

469 a stratovolcano building may last several $100 \mathrm{kyrs}$, a period mirroring that of the reservoir lying

470 below, while experiments are carried for durations varying between minutes/hours at high

471 temperature $\left(>1000^{\circ} \mathrm{C}\right)$ up to several weeks in the low end of the terrestrial temperature silicate

472 magmas spectrum $\left(\mathrm{ca} 600^{\circ} \mathrm{C}\right)$. Yet, fortunately for that matter, pre-eruptive or syn-eruptive

473 phenomena often occur on short time scales, i.e. they can, for the most part, be directly simulated

474 by laboratory experiments under the right $\mathrm{P}-\mathrm{T}$ conditions and using the natural magma as starting

475 material. Asides from the selection of starting material, in order to be relevant to the natural

476 context, experiments need to be carried out in the correct order: first, phase equilibria which set in

477 the general scene, in particular the broad P-T field of magma storage and evolution, and then the 478 dynamic experiments simulating the process (i.e., decompression, mixing, 479 assimilation/contamination/interaction).

\section{P-T conditions of magma evolution: phase equilibrium studies}

481 The most common as well as standard approach of experimental petrology studies includes

482 the elaboration of phase relationships at various pressure, temperature and volatile contents. This 
483 approach defines the stability fields of the major and minor mineral phases as a function of $\mathrm{P}, \mathrm{T}$ 484 and melt volatile content (Fig. 8). These data are fundamentally aimed at testing to what extent 485 crystal-liquid equilibria were prevailing in the reservoir prior to eruption, and they allow setting 486 the so-called pre-eruptive conditions. When such an approach is successful, i.e. when experiments 487 can define a range of P-T-volatiles conditions under which the nature, proportion and composition 488 of main phases (including liquid/glass) are reproduced, then it is reasonable to conclude that before 489 eruption the reservoir was at or near equilibrium. Conversely, inability to reproduce the 490 phenocrysts assemblage under a "reasonable" set of P-T-volatiles conditions likely points to 491 disequilibrium, whose cause could be occurrence of magma mixing or coexistence of various 492 phenocrysts having precipitated at different conditions (generally depth/pressure, or temperature) 493 before eruption.

Application of the above approach on well selected eruptions (and samples) produced by a 495 single volcano allows one to infer the time evolution of magma storage conditions (Fig. 8). This 496 is crucial since geophysical surveys can only probe the present-day state of the plumbing system, 497 which is the integrated result of all events having occurred so far. The working out of the pre498 eruptive conditions of the last event is likely to inform about the state of the reservoir most closely 499 approaching that of present-day conditions, except if the repose time since that event is very long. 500 Not all magmas erupted allow robust estimates via phase equilibrium data to be extracted however, 501 since that method depends on the variance (number of different phases) of the system under 502 consideration. An extreme case is provided by an aphyric lava or obsidian in which the lack of 503 phenocrysts prevents the simple test of crystal-liquid equilibrium. Also, some compositions are 504 saturated with the same phase assemblage over a large range of P-T-volatiles conditions, making 505 such an approach relatively imprecise. In such a case, the search for melt-inclusions trapped in 
506 phenocrysts provides a powerful assist to the definition of pre-eruption conditions, as explained 507 below. In general, however, the phase equilibrium approach has proved to be very useful in 508 providing first order P-T-volatile conditions on a number of reference volcanoes as Mt. St. Helens 509 (Rutherford et al., 1985; Gardner et al., 1995), Mt Pelée (Martel et al., 1998; Pichavant et al., 510 2002), Vesuvius (Scaillet et al., 2008; Pichavant et al., 2014), Santorini (Cottrell et al., 1999, 511 Cadoux et al., 2015; Andujar et al., 2015, 2016), Tungurahua (Andujar et al., 2017), Pinatubo 512 (Scaillet and Evans, 1999).

513 Phase equilibria provide not only a consistent picture of the stability of different phases but 514 they also furnish fundamental data on crystal-crystal or crystal-melt equilibrium partitioning for 515 some key elements ( $\mathrm{Fe}, \mathrm{Mg}, \mathrm{Cl}, \mathrm{F}$ etc.). Firstly, these allow to evaluate for each crystal pair or 516 isolated individual the equilibrium status with respect to its immediate surrounding. Secondly, 517 combined with thermodynamic principles, these data allow derivation of a variety of hygro-oxy518 thermo-barometers which allow to further refine the determination of intensive parameters. The 519 Fe-Ti oxide oxythermometer is certainly one of the most popular and accurate crystal-crystal 520 equilibrium (e.g., Andersen and Lindsley, 1993; Ghiorso and Evans, 2008; Evans et al., 2016) 521 which calculates temperature to perhaps better than $20-30^{\circ} \mathrm{C}$ and $\mathrm{fO}_{2}$ to within $0.3 \log$ units. 522 Another similarly powerful and accurate assemblage is the two-feldspars thermometer (e.g., 523 Fuhrman and Lindsley, 1988). The plagioclase-liquid hygrometer has been shown to be of great 524 assist for inferring dissolved water content of pre- to syn-eruptive melt (Waters and Lange, 2015). 525 Amphibole composition also varies widely as a function of phase assemblage, melt composition 526 and $\mathrm{P}-\mathrm{T}-\mathrm{fO}_{2}-\mathrm{fH}_{2} \mathrm{O}$ conditions, which has led to many empirical parametrizations (e.g., Johnson 527 and Rutherford, 1989; Ridolfi et al., 2010; Putirka, 2016). Apatite, which is a ubiquitous accessory 528 mineral in magmas, is being increasingly used as a monitor of melt volatile contents, the focus 
529 being on halogens and sulfur species (e.g., Parat and Holtz, 2005; Webster and Piccoli, 2015).

530 Whenever possible, combination of phase relationships with crystal-crystal and crystal-liquid 531 partitioning, as well as with MI data, should be the strategy of choice to provide robust constraints

532 on the conditions of magma evolution and storage.

\section{Constraints to magma degassing: volatile solubilities}

This part represents an important strand of the experimental approach, owing to the strong

535 pressure dependence of volatiles concentration in silicate melts with pressure, and the important

536 role that volatiles play in driving volcanic eruptions. Since the early developments of experimental

537 petrology, determining the solubilities of $\mathrm{H}_{2} \mathrm{O}$ and $\mathrm{CO}_{2}$, the two most abundant species of

538 magmatic gases, has been a priority for the community (e.g., Blank et al 1993; Dixon et al., 1995;

539 Lesne et al., 2011; Shiskhina et al., 2014). These works have largely shown that water solubility

540 is much greater than that of $\mathrm{CO}_{2}$ (Fig. 9a), hence the exsolution of the two species varies widely

541 with pressure and the bulk of water is exsolved from the silicate liquid at much lower pressure than

542 that of $\mathrm{CO}_{2}$. While the compositional control on volatile solubilities is demonstrable, it remains

543 relatively small for water but appreciable for $\mathrm{CO}_{2}$. Experimental data gathered over the last three

544 decades have allowed the development of multicomponent solubility models (e.g., Newman and

545 Lowenstern, 2002; Papale et al., 2006; Burgisser et al., 2015) whose prime use is the determination

546 of the pressure of magma-gas saturation as a function of dissolved $\mathrm{H}_{2} \mathrm{O}$ and $\mathrm{CO}_{2}$ contents

547 (Anderson et al., 1989). Application of these models to MIs enables one to calculate minimum

548 pressures for those melt aliquots, which can be compared with pressures inferred from phase

549 equilibrium considerations or geophysical constraints. Refinement of this method includes the

550 incorporation of other volatile species, in particular $\mathrm{SO}_{2}$ and $\mathrm{H}_{2} \mathrm{~S}$ (e.g., Moretti et al., 2003;

551 Clemente et al., 2004; Lesne et al., 2015) or halogens (Alletti et al., 2012). In general, however, 
552 the partial pressures of $\mathrm{H}_{2} \mathrm{O}$ and $\mathrm{CO}_{2}$ represent more than $90 \%$ of the total pressure. An important 553 output of volatile solubilities, in particular of the so-called minor species (S-bearing species and 554 halogens), is that they impose limits on absolute quantities of volatile species that a given silicate 555 melt may dissolve. Knowing such a limit allows for the determination of the magma volume 556 implied at depth to sustain gas emissions measured during an eruptive period, either effusive or 557 explosive. This is, however, possible only when there is no excess gas phase (bubble) in the 558 reservoir. Bubbles may indeed store a dominant part of some volatile species (C- and S-bearing):

559 the use of S or C fluxes measured at the surface in terms of magma mass stored at depth would 560 require knowing the amount of bubbles in the reservoir, a quantity notoriously difficult to estimate 561 (e.g., Wallace et al., 1995, Papale, 2005).

562 The determination of volatile solubilities allows also for the calculation of gas composition 563 at equilibrium with the magma either in the reservoir (Scaillet and Pichavant, 2003) or during its 564 upraise toward the surface (Burgisser and Scaillet, 2007). This application offers potentially a 565 powerful tool for the interpretation of volcanic gas compositions measured at the surface in active 566 volcanic areas (Fig. 9b). It is indeed well documented that fluctuations in gas compositions occur 567 prior or during eruptions (e.g., Allard et al., 2005; Burton et al., 2007; Aiuppa et al., 2010; 568 Oppenheimer et al., 2011; Burgisser et al., 2012), but the interpretation in terms of processes still 569 remains elusive. Changes in gas composition with eruptive style are apparent in many cases, yet 570 the real challenge is the detection of precursor gas signals related to unrest phases. A quantitative 571 as well as predictive use of such an approach, requires the modelling of gas-melt equilibria but 572 also gas-melt-crystal equilibria as crystals can hold a significant amount of volatile species 573 (sulfides, sulfates, brines). It also requires integrating the effect of aquifers which can scrub out 574 soluble species from the uprising gas $\left(\mathrm{SO}_{2}\right.$ in particular, or $\left.\mathrm{HCl}\right)$, therefore altering the surface 
575 signal (Symonds et al., 2001). This field is one of very active research, owing to the many 576 parameters intervening, their coupled character as well as feedback effects (Chiodini et al., 2016).

\section{Experimental constraints to magma mixing/interaction}

579 in magmatic reservoirs (Sparks et al., 1978). Mixing can take place between magmas differing

580 widely in composition (and rheological properties) or between compositionally similar end-

581 members. Regardless, one of the key-controlling factors of mixing efficiency appears to be the

582 viscosity contrast between juxtaposed magmas, mixing being promoted when both end-members

583 share the same viscosity. Another important parameter is density, particularly when magma

584 blending produces density inversion, since this can lead to chamber-wide convection and eruption.

585 Experiments have tackled mixing using a variety of approaches. Firstly, by juxtaposing magmas

586 with contrasted compositions under static conditions and measuring diffusion exchange at their

587 interface for different run durations (Wyllie et al., 1989). This gives insight into the time scales

588 necessary to generate diffusion profiles sometimes observed in quenched mixtures. Secondly,

589 torsion experiments, done mostly at one bar (i.e. under dry conditions), have allowed to explore

590 the role of shear rate across the interface (e.g., Kouchi and Sunagawa et al., 1985; Campos et al.,

591 2011), showing that high shear rates, such as in volcanic conduits, facilitate mixing, even with

592 high viscosity contrast. The geochemical patterns obtained in such high temperature experiments

593 have been also used to infer the contact time between mixed magmas in volcanic products (e.g.,

594 Perugini et al., 2008; Rossi et al., 2017). More recently, torsion experiments at high pressure (i.e.

595 with hydrous magmas) have demonstrated that mixing between felsic and mafic magmas in

596 reservoirs (i.e., at low strain rates as compared to that in volcanic conduits) occurs only when the

597 viscosity contrast is null (Fig. 10; Laumonier et al., 2014). These experiments provide constraints 
598 on the relative amounts between invading and resident magmas needed to achieve homogeneous

599 mixtures at the hand scale (Fig. 11): the experiments and ensuing calculations show that true

600 hybrids require in general equal amounts of mafic and felsic magmas, a too small amount

601 preventing the production of intermediate magmas in any significant volume. At a somewhat

602 smaller scale, experiments have also investigated the rate of diffusive equilibration of crystals

603 exposed to changing P-T or chemical conditions. As stated above, the preservation of chemical

604 zoning in many phenocrysts (olivine, feldspars, pyroxenes, oxides), and their interpretation in

605 terms of relaxation time scale, offer a powerful tool for gauging the residence times of crystals in

606 magmas. This approach most often concludes to relatively short time scales of attending magmatic

607 processes (i.e. magma recharge) occurring before eruption, from hours to months to decades (e.g.,

608 Costa et al., 2003; Druitt et al., 2012).

609 Experiments can also explore how a magma, once intruded in the crust to build a shallow

610 reservoir, interacts with its surroundings. Of particular interest in the context of volcanic processes

611 is the ingestion by the magma of volatile-rich country rocks. Contamination of the magma by

612 evaporites, carbonates or coal-rich sediments has the potential to liberate a variety of S- and C-

613 species which will add to the initial content of those elements of the magma. Recognition of such

614 a process is important since it affects the interpretation of gas fluxes measured at the surface (e.g.,

615 Di Rocco et al., 2012). Whenever this happens, the mass of volatiles expelled cannot be used to

616 make inferences about the amount of the magma source of these emissions, unless isotopic

617 discrimination between magma and host rock volatiles is possible. The contamination process not

618 only affects the volatile budget of the magma but also its redox state which in turn affects gas

619 speciation, with these interactions being progressively able to affect the magma chemical evolution

620 (Iacono-Marziano et al., 2008, 2012). Such an evolution can be in turn correlated to a change of 
621 the plumbing system (nature of the host rock with depth). If good inferences can be made about

622 the host rock (generally by looking at xenoliths carried by the magmas), interaction experiments

623 can thus provide important constraints on the plumbing system and the way it affects magma

624 evolution and its surface manifestations (i.e. gas composition). Fluxing of externally generated

625 volatiles through a magma reservoir can also induce important variations in the volatile solubility

626 of the magma, changing the composition (and partial pressure) of the coexisting fluids (Spilliaert

627 et al., 2005; Dallai et al., 2011).

\section{Constraints to the rates of magma ascent: decompression experiments}

This category of experiments is obviously the one more closely simulating magma ascent in

630 a conduit. The fundamental parameter that those experiments strive to constrain is the magma

631 ascent rate and its potential variation during the eruptive sequence. Textural features that

632 experiments aim at replicating are crystal and bubble size distributions. Compositional features are

633 primarily microlite compositions and glass volatile contents. For the latter, the contrasted kinetics

634 of volatile species diffusion afford potentially a powerful speedometer. However, given the

635 difficulty in quantitatively analyzing dissolved volatiles in quenched experimental run products,

636 efforts have focused mostly on reproducing bubble (e.g., Mangan and Sisson, 2000; Mourtada-

637 Bonnefoi and Laporte, 2004; Gardner and Ketcham, 2011; Martel and Iacono-Marziano, 2015; Le

638 Gall and Pichavant, 2016) and microlite (e.g., Hammer et al., 1999; Martel, 2012) characteristics.

639 This category of experiments show that it is possible to simulate accurately the texture of volcanic

640 rocks, giving strong confidence on the reliability of the constrained parameter. Ascent rates

641 inferred from such an approach show that the transit time between magma reservoir and the sub-

642 surface varies from hours to days, depending on eruptive dynamics and magma composition. 
Decompression experiments have the potential to unravel in considerable detail the

644 behavior of volatiles during magma ascent (e.g., Fiege et al., 2015; Le Gall and Pichavant, 2016).

645 This is important because such a knowledge helps to understand not only the physical effects

646 associated to volatile exsolution (i.e. when bubbles nucleate and how they grow) but also the

647 associated chemical effects: the latter arise because of the differing kinetics of volatile species

648 diffusion in silicate melts (Watson, 1994; Baker et al., 2005), slower diffusing species $\left(\mathrm{CO}_{2}, \mathrm{~S}-\right.$

649 bearing) lagging behind (i.e. remaining within the melt) species with high mobility $\left(\mathrm{H}_{2} \mathrm{O}, \mathrm{H}_{2}\right)$. This

650 diffusive fractionation of volatile species will in turn affect gas composition, that will necessarily

651 differ from the one which can be calculated under the equilibrium assumption, using known

652 solubility laws (Fig. 12). Essentially, gas produced during fast magma ascent will be richer in $\mathrm{H}_{2} \mathrm{O}$

653 than predicted by equilibrium (Pichavant et al., 2013), though the details of chemical effects

654 associated to decompression still remain largely unexplored. This comparatively new field of

655 research, made possible by the improved performances of laboratory experiments and micro-

656 analytical tools (ion probe or infra-red spectroscopy), will expand in the next coming years.

\section{Measuring physical properties of rocks and magmas}

This is also a rapidly expanding field that aims at defining the physical properties of rocks

659 and magmas under their natural conditions. A master property that has fuelled numerous laboratory

660 studies is magma viscosity. Thanks to a wealth of experimental data, acquired on either dry or

661 hydrous systems, there are now efficient models for calculating melt viscosities under a large range

662 of T-volatiles conditions (e.g., Giordano et al., 2008). The effects of crystals and bubbles (e.g.,

663 Bagdassarov and Dingwell, 1992; Rust and Manga, 2002) have been also extensively explored,

664 these efforts enabling the elaboration of various accurate models of magma rheology (e.g., Costa,

665 2005; Mader et al., 2013). The role of strain rate on magma rheology has been also explored at 
666 high pressure (e.g., Caricchi et al., 2011). These data primarily serve to inform numerical 667 simulations of magma flow (within reservoirs or conduits) whose performances heavily depend on 668 the robustness of the constitutive laws used for describing material properties, and their evolution 669 with intensive parameters (e.g., Costa et al., 2011). The conditions leading to magma or host rock 670 fracture, and the measurement of associated signals, is evidently an important field of research 671 (e.g., Benson et al., 2012; Heap et al., 2015; Vasseur et al., 2018), although still in its infancy 672 owing to the variety of lithologies and conditions involved in nature.

673 Laboratory experiments also helps to interpret the geophysical signals measured at the 674 surface (seismicity, conductivity, gravimetry, etc.) which are used to image magma bodies beneath 675 volcanoes. Although technically challenging, the attenuation of the velocity of seismic waves with 676 fraction of melt/fluid has been studied at high pressure and high temperature, but the difference in 677 frequency between natural and laboratory waves is a complicating factor for data application 678 (Caricchi et al., 2008). In-situ measurements allow now to measure directly the density of hydrous 679 melts at high pressure (Malfait et al., 2014), which should be of considerable help for interpreting 680 gravimetric anomalies in volcanic areas. Finally, it is now possible to measure with great precision 681 the variation of the electrical conductivity of melts with their composition, including their volatile 682 contents (Gaillard, 2004; Pommier et al., 2010). These data help illuminate the volcanological 683 significance of magnetotelluric signals detected in active volcanic areas (Pommier et al., 2008). 684 As knowledge is gained in the next coming years, the combination of the above data along with 685 joint inversion of surface signals should considerably improve our ability to detect not only magma 686 bodies, even those small, but also the precursor signals associated to magma upraise or recharge 687 associated to unrest phases. 


\section{Discussion and Conclusions}

690 In the last few decades, disciplines such as physical volcanology and petrology have moved

691 from qualitative and descriptive approaches towards a more quantitative approach for the

692 understanding of magmatic and volcanic processes. This advancement produced a huge amount of

693 new data on volcanic deposits, mineral and melt components of volcanic rocks, and generated new

694 ideas and perspectives on laboratory experiments and physical models. By merging these data with

695 those produced by other disciplines (e.g. geophysics), new conceptual models on how volcanoes

696 work have arisen and more precise information on the size and internal dynamics of volcanic

697 systems have been obtained. The most important advancements in this framework have been

698 established at volcanoes with persistent activity or with high eruptive frequency, where hypotheses

699 and conceptual models can be continuously elaborated, tested and refined.

700 A holistic, multidisciplinary view of volcanic systems through the study of their different

701 portions and products is the only way to reach a robust understanding of the large set of processes

702 which control their activity. A real step forward in the general understanding of a volcanic system

703 can only be obtained starting from the detailed, basic knowledge of its structure and deposits

704 derived from volcanological investigations in the field (geological and structural mapping,

705 geochronology, stratigraphy and sedimentology of the deposits), passing through the physical

706 volcanological characterization of products and eruptions, up to the most accurate, refined

707 petrological studies of the main single processes controlling the volcanic system.

708 Field volcanology studies represent always the main door to the knowledge of a volcanic

709 system. The under consideration of the geological evolution of a volcanic system can in fact result

710 in a strongly biased reconstruction of the complex set of processes governing and modulating its

711 life. Planning of stratigraphic and mapping work should be always implemented when assessing 
712 volcanic hazards or defining the spectrum of eruption scenarios at a volcano. Additionally, data

713 already available for the volcanoes of interest should be always critically revised in the light of

714 new views on volcanic activity and products, instead of accepting them uncritically. Studies of on-

715 going activity are generally strongly preferred in order to understand the dynamics of volcanic

716 activity, but the study of the deposits of past eruptions still remains a unique tool to define the

717 range of possible eruption scenarios at a given volcano.

718 Eruptive activity is strictly related to the physico-chemical conditions of the magma driving

719 the eruption. At the same time, the temporal evolution of a magmatic system is strictly controlled

720 by changes in the magma source or in the physical conditions of magma evolution. For these

721 reasons, the petrological characterization of the erupted products and of their temporal variations

722 can provide important data to derive direct indications on the significance of these processes.

723 Based on all this knowledge, experimental petrology can be used to reproduce effectively in the

724 lab the conditions of magma evolution, ascent and eruption to the surface, adding new, quantitative 725 estimations of the main parameters which control all these processes.

726 Hazard assessment and eruption scenario definition for a volcano should be always based on

727 the deep, direct knowledge of the range of parameters which control its activity and evolution, in 728 the view that each volcano is characterized by its own "personality".

\section{$731 \quad$ References}

732 Acocella, V. (2007). Understanding caldera structure and development: An overview of analogue 733 models compared to natural calderas. Earth-Science Reviews, 85(3-4), 125-160. 
734 Acocella, V. (2014). Structural control on magmatism along divergent and convergent plate 735 boundaries: Overview, model, problems. Earth-Science Reviews, 136, 226-288.

736 Acocella, V., Porreca, M., Neri, M., Mattei, M., \& Funiciello, R. (2006). Fissure eruptions at 737 Mount Vesuvius (Italy): insights on the shallow propagation of dikes at volcanoes. $738 \quad$ Geology, 34(8), 673-676.

739 Aiuppa, A., Burton, M., Caltabiano, T., Giudice, G., Guerrieri, S., Liuzzo, M., Murè F., \& 740 Salerno, G. (2010). Unusually large magmatic CO2 gas emissions prior to a basaltic 741 paroxysm. Geophysical Research Letters, 37(17).

742 Albert, H., Costa, F. \& Marti, J. 2015. Timing of Magmatic Processes and Unrest Associated with Mafic Historical Monogenetic Eruptions in Tenerife Island. Journal of Petrology, 56, 1945-1966, doi: 10.1093/petrology/egv058.

Albert, H., Costa, F. \& Marti, J. 2016. Years to weeks of seismic unrest and magmatic intrusions precede monogenetic eruptions. Geology, 44, 211-214, doi: 10.1130/G37239.1.

Allard, P., Burton, M., \& Muré, F. (2005). Spectroscopic evidence for a lava fountain driven by previously accumulated magmatic gas. Nature, 433(7024), 407.

Alletti, M., Burgisser, A., Scaillet, B., \& Oppenheimer, C. (2014). Chloride partitioning and solubility in hydrous phonolites from Erebus volcano: A contribution towards a multicomponent degassing model. GeoResJ, 3, 27-45.

Andersen, D. J., Lindsley, D. H., \& Davidson, P. M. (1993). QUILF: A pascal program to assess equilibria among $\mathrm{Fe} \quad \mathrm{Mg} \quad \mathrm{Mn} \quad$ Ti oxides, pyroxenes, olivine, and quartz. Computers \& Geosciences, 19(9), 1333-1350. 
Anderson Jr, A. T., Newman, S., Williams, S. N., Druitt, T. H., Skirius, C., \& Stolper, E. (1989). H2O, CO2, CI, and gas in Plinian and ash-flow Bishop rhyolite. Geology, 17(3), 221225.

758

759

Andújar, J., Martel, C., Pichavant, M., Samaniego, P., Scaillet, B., \& Molina, I. (2017). Structure of the plumbing system at Tungurahua volcano, Ecuador: insights from phase equilibrium experiments on July-August 2006 eruption products. Journal of Petrology, 58(7), 12491278.

Andújar, J., Scaillet, B., Pichavant, M., \& Druitt, T. H. (2015). Differentiation conditions of a basaltic magma from Santorini, and its bearing on the production of andesite in arc settings. Journal of Petrology, 56(4), 765-794.

Andújar, J., Scaillet, B., Pichavant, M., \& Druitt, T. H. (2016). Generation conditions of dacite and rhyodacite via the crystallization of an andesitic magma. Implications for the plumbing system at Santorini (Greece) and the origin of tholeiitic or calc-alkaline differentiation trends in arc magmas. Journal of Petrology, 57(10), 1887-1920.

Armienti, P. 2008. Decryption of Igneous Rock Textures: Crystal Size Distribution Tools. Reviews in Mineralogy and Geochemistry, 69, 623-649, doi: 10.2138/rmg.2008.69.16.

Armienti, P., Perinelli, C. \& Putirka, K.D. 2013. A New Model to Estimate Deep-level Magma Ascent Rates, with Applications to Mt. Etna (Sicily, Italy). Journal of Petrology, 54, 795813, doi: 10.1093/petrology/egs085.

Asimow, P., Dixon, J. \& Langmuir, C. 2004. A hydrous melting and fractionation model for midocean ridge basalts: Application to the Mid-Atlantic Ridge near the Azores. Geochemistry Geophysics Geosystems, 5. 
Azzaro, R., Branca, S., Gwinner, K., \& Coltelli, M. (2012). The volcano-tectonic map of Etna volcano, 1: 100.000 scale: an integrated approach based on a morphotectonic analysis from high-resolution DEM constrained by geologic, active faulting and seismotectonic data. Italian Journal of Geosciences, 131(1), 153-170.

Bacon, C. R. (1986). Magmatic inclusions in silicic and intermediate volcanic rocks. Journal of Geophysical Research: Solid Earth, 91(B6), 6091-6112.

Bagdassarov, N. S., \& Dingwell, D. B. (1992). A rheological investigation of vesicular rhyolite. Journal of volcanology and geothermal research, 50(3), 307-322.

Baker, D. R., Freda, C., Brooker, R. A., \& Scarlato, P. (2005). Volatile diffusion in silicate melts and its effects on melt inclusions. Annals of Geophysics, 48(4-5).

Barberi F, Coltelli M, Frullani A, Rosi, M., Almeida, E. (1995) Chronology and dispersal characteristics of recently (last 5000 years) erupted tephra of Cotopaxi (Ecuador): implications for long-term eruptive forecasting. Journal of Volcanology and Geothermal Research 69:217-239.

Barsotti, S., Neri, A., \& Scire, J. S. (2008). The VOL-CALPUFF model for atmospheric ash dispersal: 1. Approach and physical formulation. Journal of Geophysical Research: Solid Earth, 113(B3).

Benson, P. M., Heap, M. J., Lavallee, Y., Flaws, A., Hess, K. U., Selvadurai, A. P. S., ... \& Schillinger, B. (2012). Laboratory simulations of tensile fracture development in a volcanic conduit via cyclic magma pressurisation. Earth and Planetary Science Letters, $349,231-239$. 
Blank, J. G., Stolper, E. M., \& Carroll, M. R. (1993). Solubilities of carbon dioxide and water in rhyolitic melt at $850 \mathrm{C}$ and 750 bars. Earth and Planetary Science Letters, 119(1-2), 2736.

Blundy, J., \& Cashman, K. (2001). Ascent-driven crystallisation of dacite magmas at Mount St Helens, 1980-1986. Contrib Mineral Petrol 140, 631-650. doi:10.1007/s004100000219

Blundy, J., \& Cashman, K. (2008). Petrologic reconstruction of magmatic system variables and processes. Reviews in Mineralogy and Geochemistry, 69(1), 179-239.

Bonadonna, C., Biass, S., Costa, A. (2015). Physical characterization of explosive volcanic eruptions based on tephra deposits: propagation of uncertainties and sensitivity analysis. Journal of Volcanology and Geothermal Research, 296, 80-100. doi:10.1016/j.jvolgeores.2015.03.009

Bonadonna, C., Cioni, R., Costa, A., Druitt, T., Phillips, J., Pioli, L., Andronico, D., Harris, A., Scollo, S., Bachmann, O.Bagheri, G. (2016). MeMoVolc report on classification and dynamics of volcanic explosive eruptions. Bulletin of Volcanology, 78(11), p.84.

Bonadonna, C., Cioni, R., Pistolesi, M., Connor, C., Scollo, S., Pioli, L., \& Rosi, M. (2013). Determination of the largest clast sizes of tephra deposits for the characterization of explosive eruptions: a study of the IAVCEI commission on tephra hazard modelling. Bulletin of Volcanology, 75(1), 680.

Bonadonna, C., Ernst, G. G. J., \& Sparks, R. S. J. (1998). Thickness variations and volume estimates of tephra fall deposits: the importance of particle Reynolds number. Journal of Volcanology and Geothermal Research, 81(3-4), 173-187.

Brown, S. K., Crosweller, H. S., Sparks, R. S. J., Cottrell, E., Deligne, N. I., Guerrero, N. O., Hobbs, L., Kiyosugi, K., Loughlin, S. C., Siebert, L., \& Takarada, S. (2014). 
Characterisation of the Quaternary eruption record: analysis of the Large Magnitude Explosive Volcanic Eruptions (LaMEVE) database. Journal of Applied Volcanology, 3(1), 5.

824 Burgisser, A., \& Scaillet, B. (2007). Redox evolution of a degassing magma rising to the surface. Nature, 445(7124), 194.

826

827

828

829

830

832

833

834

835

836

Burgisser, A., Alletti, M., \& Scaillet, B. (2015). Simulating the behavior of volatiles belonging to the $\mathrm{C}-\mathrm{O}-\mathrm{H}-\mathrm{S}$ system in silicate melts under magmatic conditions with the software DCompress. Computers \& Geosciences, 79, 1-14.

Burgisser, A., Oppenheimer, C., Alletti, M., Kyle, P. R., Scaillet, B., \& Carroll, M. R. (2012). Backward tracking of gas chemistry measurements at Erebus volcano. Geochemistry, Geophysics, Geosystems, 13(11).

Burton, M., Allard, P., Muré, F., \& La Spina, A. (2007). Magmatic gas composition reveals the source depth of slug-driven Strombolian explosive activity. Science, 317(5835), 227-230.

Cadoux, A., Scaillet, B., Druitt, T. H., \& Deloule, E. (2014). Magma storage conditions of large Plinian eruptions of Santorini Volcano (Greece). Journal of Petrology, 55(6), 1129-1171.

Carey, S., \& Sigurdsson, H. (1986). The 1982 eruptions of El Chichón volcano, Mexico (2): Observations and numerical modelling of tephra-fall distribution. Bulletin of Volcanology, 48(2-3), 127-141.

Carey, S., \& Sparks, R. S. J. (1986). Quantitative models of the fallout and dispersal of tephra from volcanic eruption columns. Bulletin of volcanology, 48(2-3), 109-125.

Caricchi, L., Burlini, L., \& Ulmer, P. (2008). Propagation of P and S-waves in magmas with different crystal contents: Insights into the crystallinity of magmatic reservoirs. Journal of Volcanology and Geothermal Research, 178(4), 740-750. 
844 Caricchi, L., Pommier, A., Pistone, M., Castro, J., Burgisser, A., \& Perugini, D. (2011). Straininduced magma degassing: insights from simple-shear experiments on bubble bearing melts. Bulletin of volcanology, 73(9), 1245-1257.

847 Cas, R., \& Wright, J. (1987). Volcanic successions modern and ancient: A geological approach to processes, products and successions. Springer Science \& Business Media.

849 Cashman, K. \& Marsh, B. 1988. Crystal Size distribution in rocks and the kinetics and dynamics of crystallization II. Makaopuhi lava lake. Contributions to Mineralogy and Petrology, 99,

852 Cashman, K. 1992. Groundmass crystallization of Mount St. Helens dacite, 19880-1986: a tool for interpreting shallow magmatic processes. Contributions to Mineralogy and Petrology, 109,

Cashman, K., \& Blundy, J. (2000). Degassing and crystallization of ascending andesite and dacite. Philosophical Transactions: Mathematical, Physical and Engineering Sciences 358, 14871513.

Cashman, K.V., Sparks, R.S.J. \& Blundy, J.D. 2017. Vertically extensive and unstable magmatic systems: A unified view of igneous processes. Science, 355, eaag3055-11, doi: 10.1126/science.aag3055.

863 Chamberlain, K.J., Morgan, D.J. \& Wilson, C.J.N. 2014. Timescales of mixing and mobilisation 864 in the Bishop Tuff magma body: perspectives from diffusion chronometry. Contributions to Mineralogy and Petrology, 168, 563-24, doi: 10.1007/s00410-014-1034-2. 
866 Charlier, B.L.A., Morgan, D.J., Wilson, C.J.N., Wooden, J.L., Allan, A.S.R. \& Baker, J.A. 2012. Lithium concentration gradients in feldspar and quartz record the final minutes of magma ascent in an explosive supereruption. Earth and Planetary Science Letters, 319-320, 218

Chiodini, G., Paonita, A., Aiuppa, A., Costa, A., Caliro, S., De Martino, P., Acocella, V. and Vandemeulebrouck, J. (2016). Magmas near the critical degassing pressure drive volcanic unrest towards a critical state. Nature communications, 7, 13712.

873 Cioni, R. (1993). Il complesso di Bolsena e il vulcanismo alcalino-potassico del Lazio settentrionale. Ph. D. thesis.

875 Cioni, R. (2000). Volatile content and degassing processes in the AD 79 magma chamber at Vesuvius (Italy). Contributions to Mineralogy and Petrology, 140(1), 40-54.

877 Cioni, R., Bertagnini, A., Santacroce, R., \& Andronico, D. (2008). Explosive activity and eruption scenarios at Somma-Vesuvius (Italy): towards a new classification scheme. Journal of Volcanology and Geothermal Research, 178(3), 331-346.

880 Cioni, R., Gurioli, L., Sbrana, A., \& Vougioukalakis, G. (2000). Precursory phenomena and destructive events related to the Late Bronze Age Minoan (Thera, Greece) and AD 79 (Vesuvius, Italy) Plinian eruptions; inferences from the stratigraphy in the archaeological areas. Geological Society, London, Special Publications, 171(1), 123-141. destructive events related to the Late Bronze Age Minoan (Thera, Greece) and AD 79 (Vesuvius, Italy) Plinian eruptions; inferences from the stratigraphy in the archaeological areas. Geological Society, London, Special Publications 171, 123-141. 
888 Clemente, B., Scaillet, B., \& Pichavant, M. (2004). The solubility of sulphur in hydrous rhyolitic melts. Journal of Petrology, 45(11), 2171-2196.

890 Collins, B. D., \& Dunne, T. (1986). Erosion of tephra from the 1980 eruption of Mount St. Helens. Geological Society of America Bulletin, 97(7), 896-905.

892 Collins, S.J., Pyle, D.M. \& Maclennan, J. 2009. Melt inclusions track pre-eruption storage and 893 dehydration of magmas at Etna. Geology, 37, 571-574, doi: 10.1130/G30040A.1.

894 Coltelli, M., Del Carlo, P., Pompilio, M. \& Vezzoli, L. 2005. Explosive eruption of a picrite: The 3930 BP subplinian eruption of Etna volcano (Italy). Geophysical Research Letters, 32, 14, doi: 10.1029/2005GL024271.

898 Corsaro, R.A. \& Métrich, N. 2016. Chemical heterogeneity of Mt. Etna magmas in the last $15 \mathrm{ka}$. Inferences on their mantle sources. Lithos, 252-253, 123-134, doi: 10.1016/j.lithos.2016.02.006.

901 Corsaro, R.A. \& Pompilio, M. 2004a. Buoyancy-controlled eruption of magmas at Mt Etna. Terra Nova, 16, 16-22, doi: 10.1046/j.1365-3121.2003.00520.x.

903 Corsaro, R.A. \& Pompilio, M. 2004b. Magma dynamics in the shallow plumbing system of Mt. Etna as recorded by compositional variations in volcanics of recent summit activity (19951999). Journal of Volcanology and Geothermal Research, 137, 55-71, doi:

907 Corsaro, R.A., Civetta, L., Di Renzo, V. \& Miraglia, L. 2009a. Petrology of lavas from the 2004908 2005 flank eruption of Mt. Etna, Italy: inferences on the dynamics of magma in the shallow plumbing system. Bulletin of Volcanology, 71, 781-793, doi: 10.1007/s00445-009-0264Z. 
911 Corsaro, R.A., Metrich, N., Allard, P., Andronico, D., Miraglia, L. \& Fourmentraux, C. 2009 b.

912 The 1974 flank eruption of Mount Etna: An archetype for deep dike-fed eruptions at

913 basaltic volcanoes and a milestone in Etna's recent history. Journal of Geophysical

914 Research Solid Earth, 114,-, doi: 10.1029/2008JB006013.

915 Corsaro, R.A., Miraglia, L. \& Pompilio, M. 2007. Petrologic evidence of a complex plumbing 916 system feeding the July-August 2001 eruption of Mt. Etna, Sicily, Italy. Bulletin of 917 Volcanology, 69, 401-421, doi: 10.1007/s00445-006-0083-4.

918 Costa, A. (2005). Viscosity of high crystal content melts: dependence on solid fraction.

919 Geophysical Research Letters,

920 Costa, A., Melnik, O., Sparks, R. S. J., \& Voight, B. (2007). Control of magma flow in dykes on $921 \quad$ cyclic lava dome extrusion. Geophysical Research Letters, 34(2).

922 Costa, F., Chakraborty, S., \& Dohmen, R. (2003). Diffusion coupling between trace and major 923 elements and a model for calculation of magma residence times using plagioclase.

924 Geochimica et Cosmochimica Acta, 67(12), 2189-2200.

925 Crisp, J. A. (1984). Rates of magma emplacement and volcanic output. Journal of Volcanology 926 and Geothermal Research, 20(3-4), 177-211.

927 D’Oriano, C., Bertagnini, A. \& Pompilio, M. 2011. Ash erupted during normal activity at 928 Stromboli (Aeolian Islands, Italy) raises questions on how the feeding system works. 929 Bulletin of Volcanology, 73, 471-477, doi: 10.1007/s00445-010-0425-0.

930 Dallai L, Cioni R, Boschi C, D’Oriano C (2011) Carbonate-derived CO2 purging magma at depth: 931 Influence on the eruptive activity of Somma-Vesuvius, Italy. Earth and Planetary Science 932 Letters 310: 84-95. doi: 10.1016/j.eps1.2011.07.013 
933 De Campos, C. P., Perugini, D., Ertel-Ingrisch, W., Dingwell, D. B., \& Poli, G. (2011).

934 Enhancement of magma mixing efficiency by chaotic dynamics: an experimental study. 935 Contributions to Mineralogy and Petrology, 161(6), 863-881.

936 Del Carlo, P. \& Pompilio, M. 2004. The relationship between volatile content and the eruptive 937 style of basaltic magma: the Etna case. Annals of Geophysics, 47, 1423-1432.

938 Del Moro, S., Di Roberto, A., et al. 2015. Xenopumice erupted on 15 October 2011 offshore of El 939 Hierro (Canary Islands): a subvolcanic snapshot of magmatic, hydrothermal and 940 pyrometamorphic processes. Bulletin of Volcanology, 77, -19, doi: 10.1007/s00445-015$941 \quad 0940-0$.

942 Di Renzo, V., Corsaro, R.A., Miraglia, L., Pompilio, M. \& Civetta, L. 2018. Long and short-term 943 magma differentiation at Mt. Etna as revealed by Sr-Nd isotopes and geochemical data. $944 \quad$ Earth Science Reviews, 190, 112-130, doi: 10.1016/j.earscirev.2018.12.008.

945 Di Rocco, T., Freda, C., Gaeta, M., Mollo, S., \& Dallai, L. (2012). Magma chambers emplaced in 946 carbonate substrate: petrogenesis of skarn and cumulate rocks and implications for CO2 947 degassing in volcanic areas. Journal of Petrology, 53(11), 2307-2332.

948 Dixon, J. E., Stolper, E. M., \& Holloway, J. R. (1995). An experimental study of water and 949 carbon dioxide solubilities in mid-ocean ridge basaltic liquids. Part I: calibration and 950 solubility models. Journal of Petrology, 36(6), 1607-1631.

951 Druitt, T. H., Costa, F., Deloule, E., Dungan, M., \& Scaillet, B. (2012). Decadal to monthly 952 timescales of magma transfer and reservoir growth at a caldera volcano. Nature, $953 \quad 482(7383), 77$. 
954 Druitt, T.H., Costa, F., Deloule, E., Dungan, M. \& Scaillet, B. 2012. Decadal to monthly timescales of magma transfer and reservoir growth at a caldera volcano. Nature, 482, 77-U97, doi: 10.1038/nature10706.

957 Engwell, S.L., Sparks, R.S.J., \& Carey, S. (2014). Physical characteristics of tephra layers in the

Evans, B. W., Hildreth, W., Bachmann, O., \& Scaillet, B. (2016). In defense of magnetiteilmenite thermometry in the Bishop Tuff and its implication for gradients in silicic magma reservoirs. American Mineralogist, 101(2), 469-482.

Eychenne, J., Le Pennec, J. L., Ramon, P., \& Yepes, H. (2013). Dynamics of explosive paroxysms at open-vent andesitic systems: high-resolution mass distribution analyses of the 2006 Tungurahua fall deposit (Ecuador). Earth and Planetary Science Letters, 361, 343-355.

Fiege, A., Vetere, F., Iezzi, G., Simon, A., \& Holtz, F. (2015). The roles of decompression rate and volatiles $(\mathrm{H} 2 \mathrm{O}+\mathrm{Cl} \pm \mathrm{CO} 2 \pm \mathrm{S})$ on crystallization in (trachy-) basaltic magma. Chemical Geology, 411, 310-322.

Fisher, R. V., \& Schmincke, H. U. (1984). Pyroclastic rocks. Springer Science \& Business Media. Francalanci, L., Tommasini, S. \& Conticelli, S. 2004. The volcanic activity of Stromboli in the 1906-1998 AD period: mineralogical, geochemical and and isotope data relevant to the understanding of the plumbing system. Journal of Volcanology and Geothermal Research.

Francalanci, L., Avanzinelli, R., Tommasini, S., Heuman, A., Beccaluva, L. \& Bianchini, G. 2007. A west-east geochemical and isotopic traverse along the volcanism of the Aeolian Island arc, southern Tyrrhenian Sea, Italy: Inferences on mantle source processes. Cenozoic volcanism in the Mediterranean area, 235. 
977 Fuhrman, M. L., \& Lindsley, D. H. (1988). Ternary-feldspar modeling and thermometry. $978 \quad$ American mineralogist, 73(3-4), 201-215.

979 Fulignati, P., Marianelli, P., Santacroce, R., \& Sbrana, A. (2004). Probing the Vesuvius magma 980 chamber-host rock interface through xenoliths. Geological Magazine, 141(4), 417-428.

981 Gaillard, F. (2004). Laboratory measurements of electrical conductivity of hydrous and dry 982 silicic melts under pressure. Earth and Planetary Science Letters, 218(1-2), 215-228.

983 Gardner, J. E., \& Ketcham, R. A. (2011). Bubble nucleation in rhyolite and dacite melts:

984 temperature dependence of surface tension. Contributions to Mineralogy and Petrology, $985 \quad 162(5), 929-943$.

986 Gardner, J. E., Rutherford, M., Carey, S., \& Sigurdsson, H. (1995). Experimental constraints on 987 pre-eruptive water contents and changing magma storage prior to explosive eruptions of 988 Mount St Helens volcano. Bulletin of Volcanology, 57(1), 1-17.

989 Gardner, J.E., Rutherford, M., Carey, S., \& Sigurdsson, H. (1995). Experimental constraints on 990 pre-eruptive water contents and changing magma storage prior to explosive eruptions of 991 Mount St Helens volcano. Bull Volcanol 57, 1-17.

992 Ghiorso, M. \& Sack, R. 1995. Chemical mass transfer in magmatic processes IV. A revised and 993 internally consistent thermodynamic model for the interpolation and extrapolation of 994 liquid-solid equilibria in magmatic systems at elevated temperatures and pressures. 995 Contributions to Mineralogy and Petrology, 119, 197-212.

996 Ghiorso, M. S., \& Evans, B. W. (2008). Thermodynamics of rhombohedral oxide solid solutions 997 and a revision of the Fe-Ti two-oxide geothermometer and oxygen-barometer. American $998 \quad$ Journal of science, 308(9), 957-1039. 
999 Ghiorso, M.S. \& Gualda, G.A.R. 2015. An H2O-CO2 mixed fluid saturation model compatible 1000 with rhyolite-MELTS. Contributions to Mineralogy and Petrology, 169, 1-30, doi: 10.1007/s00410-015-1141-8.

1002 Giaccio, B., Messina, P., Sposato, A., Voltaggio, M., Zanchetta, G., Galadini, F., Gori, S., \& 1003 1004 1005

Giordano, D., Russell, J. K., \& Dingwell, D. B. (2008). Viscosity of magmatic liquids: a model. Earth and Planetary Science Letters, 271(1-4), 123-134.

1013

Green, D., Schmidt, M. \& Hibberson, W. 2004. Island-arc ankaramites: Primitive melts from fluxed refractory lherzolitic mantle. Journal of Petrology, 45, 391-403.

Groppelli, G., \& Viereck-Goette, L. (Eds.). (2010). Stratigraphy and geology of volcanic areas (Vol. 464). Geological Society of America.

Grove, T., Parman, S., Bowring, S., Price, R. \& Baker, M. 2002. The role of an H 2 O-rich fluid component in the generation of primitive basaltic andesites and andesites from the Mt. Shasta region, N California. Contributions to Mineralogy and Petrology, 142, 375-396.

Gualda, G.A.R., Ghiorso, M.S., Lemons, R.V. \& Carley, T.L. 2012. Rhyolite-MELTS: a Modified Calibration of MELTS Optimized for Silica-rich, Fluid-bearing Magmatic Systems. Journal of Petrology, 53, 875-890, doi: 10.1093/petrology/egr080. 
1022 Gurioli, L. et alii (2015). MeMoVolc consensual document: a review of cross-disciplinary 1023 approaches to characterizing small explosive magmatic eruptions. Bulletin of Volcanology, $1024 \quad 77(6), 49$.

1025 Hammer, J. E., Cashman, K. V., Hoblitt, R. P., \& Newman, S. (1999). Degassing and microlite 1026 crystallization during pre-climactic events of the 1991 eruption of Mt. Pinatubo, 1027 Philippines. Bulletin of Volcanology, 60(5), 355-380.

1028 Hammer, J.E., Cashman, K.V., \& Voight, B. (2000). Magmatic processes revealed by textural and 1029 compositional trends in Merapi dome lavas. Journal of Volcanology and Geothermal $1030 \quad$ Research 100, 165-192.

1031 Hammer, J.E., Cashman, K.V., Hoblitt, R.P. \& Newman, S. 1999. Degassing and microlite 1032 crystallization during pre-climactic events of the 1991 eruption of Mt. Pinatubo, 1033 Philippines. Bulletin of Volcanology, 60, 355-380, doi: 10.1007/s004450050238.

1034 Hammer, J.E., Cashman, K.V., Hoblitt, R.P., \& Newman, S. (1999). Degassing and microlite 1035 1036 1037 1038 1039 Heap, M. J., Xu, T., Kushnir, A. R., Kennedy, B. M., \& Chen, C. F. (2015). Fracture of magma 1040 1041 crystallization during pre-climactic events of the 1991 eruption of Mt. Pinatubo, Philippines. Bull Volcanol 60, 355-380.

Hawkesworth, C., George, R., Turner, S., Zellmer, G., 2004. Time scales of magmatic processes. Earth and Planetary Science Letters 218, 1-16. doi:10.1016/S0012-821X(03)00634-4 containing overpressurised pores. Journal of Volcanology and Geothermal Research, 301, 180-190.

Higgins, M.D. \& Roberge, J. 2007. Three magmatic components in the 1973 eruption of Eldfell volcano, Iceland: Evidence from plagioclase crystal size distribution (CSD) and 
geochemistry. Journal of Volcanology and Geothermal Research, 161, 247-260, doi: 10.1016/j.jvolgeores.2006.12.002.

Higgins, M.D. 1996. Magma dynamics beneath Kameni volcano, Thera, Greece, as revealed by crystal size and shape measurements. Journal of Volcanology and Geothermal Research, 70, 37-48, doi: 10.1016/0377-0273(95)00045-3.

Higgins, M.D.. Quantitative Textural Measurements in Igneous and Metamorphic Petrology. Cambridge University Press.

Iacono-Marziano, G., Gaillard, F., \& Pichavant, M. (2008). Limestone assimilation by basaltic magmas: an experimental re-assessment and application to Italian volcanoes. Contributions to Mineralogy and Petrology, 155(6), 719-738.

Iacono-Marziano, G., Gaillard, F., Scaillet, B., Polozov, A. G., Marecal, V., Pirre, M., \& Arndt, N. T. (2012). Extremely reducing conditions reached during basaltic intrusion in organic matter-bearing sediments. Earth and Planetary Science Letters, 357, 319-326.

Jerram, D.A., Dobson, K.J., Morgan, D.J. \& Pankhurst, M.J. 2018. The Petrogenesis of Magmatic Systems: Using Igneous Textures to Understand Magmatic Processes. In: Volcanic and Igneous Plumbing Systems. Elsevier, 191-229. doi: 10.1016/B978-0-12-809749-6.00008$\mathrm{X}$.

Johnson, M. C., \& Rutherford, M. J. (1989). Experimental calibration of the aluminum-inhornblende geobarometer with application to Long Valley caldera (California) volcanic rocks. Geology, 17(9), 837-841.

Kahl, M., Chakraborty, S., Costa, F. \& Pompilio, M. 2011. Dynamic plumbing system beneath volcanoes revealed by kinetic modeling, and the connection to monitoring data: An 
example from Mt. Etna. Earth and Planetary Science Letters, 308, 11-22, doi: 10.1016/j.eps1.2011.05.008.

Kahl, M., Chakraborty, S., Costa, F., Pompilio, M., Liuzzo, M. \& Viccaro, M. 2013. Compositionally zoned crystals and real-time degassing data reveal changes in magma transfer dynamics during the 2006 summit eruptive episodes of Mt. Etna. Bulletin of Volcanology, 75, 692, doi: 10.1007/s00445-013-0692-7.

Kahl, M., Chakraborty, S., Pompilio, M. \& Costa, F. 2015. Constraints on the Nature and Evolution of the Magma Plumbing System of Mt. Etna Volcano (1991-2008) from a Combined Thermodynamic and Kinetic Modelling of the Compositional Record of Minerals. Journal of Petrology, 56, 2025-2068, doi: 10.1093/petrology/egv063.

Kahl, M., Viccaro, M., Ubide, T., Morgan, D.J. \& Dingwell, D.B. 2017. A Branched Magma Feeder System during the 1669 Eruption of Mt Etna: Evidence from a Time-integrated Study of Zoned Olivine Phenocryst Populations. Journal of Petrology, 58, 443-472, doi: 10.1093/petrology/egx022.

Kamenetsky, V.S., Pompilio, M., M trich, N., Sobolev, A.V., Kuzmin, D.V. \& Thomas, R. 2007. Arrival of extremely volatile-rich high-Mg magmas changes explosivity of Mount Etna. Geology, 35, 255, doi: 10.1130/G23163A.1.

Kent, A. J. (2008). Melt inclusions in basaltic and related volcanic rocks. Reviews in Mineralogy and Geochemistry, 69(1), 273-331.

Kouchi, A., \& Sunagawa, I. (1985). A model for mixing basaltic and dacitic magmas as deduced from experimental data. Contributions to Mineralogy and Petrology, 89(1), 17-23.

Landi, P., Corsaro, R., Francalanci, L., Civetta, L., Miraglia, L., Pompilio, M. \& Tesoro, R. 2008. Magma dynamics during the 2007 Stromboli eruption (Aeolian Islands, Italy): 
Mineralogical, geochemical and isotopic data. Journal of Volcanology and Geothermal Research.

1091 Landi, P., Francalanci, L., et al. 2006. The December 2002-July 2003 effusive event at Stromboli 1092

Laumonier, M., Scaillet, B., Pichavant, M., Champallier, R., Andujar, J., \& Arbaret, L. (2014). On the conditions of magma mixing and its bearing on andesite production in the crust.

Le Gall, N., \& Pichavant, M. (2016). Experimental simulation of bubble nucleation and magma 1099 ascent in basaltic systems: Implications for Stromboli volcano. American Mineralogist,

1101 Lesne, P., Scaillet, B., \& Pichavant, M. (2015). The solubility of sulfur in hydrous basaltic melts. Chemical Geology, 418, 104-116.

1103 Lesne, P., Scaillet, B., Pichavant, M., Iacono-Marziano, G., \& Beny, J. M. (2011). The H 2 O 1104 solubility of alkali basaltic melts: an experimental study. Contributions to Mineralogy

1106 Longpré, M.A., Klugel, A., Diehl, A. \& Stix, J. 2014. Mixing in mantle magma reservoirs prior to 1107 and during the 2011-2012 eruption at El Hierro, Canary Islands. Geology, doi: 10.1130/G35165.1.

1109 Lowenstern, J. B. (2003). Melt inclusions come of age: volatiles, volcanoes, and Sorby's legacy. 1110 In Developments in Volcanology (Vol. 5, pp. 1-21). Elsevier. 
1111 Mader, H. M., Llewellin, E. W., \& Mueller, S. P. (2013). The rheology of two-phase magmas: A 1112 review and analysis. Journal of Volcanolog

1113 Mangan, M. 1990. Crystal size distribution systematics and the determination of magma storage 1114 times: the 1959 eruption of Kilauea volcano, Hawaii. Journal of Volcanology and 1115 Geothermal Researches, 44, 295-302.

1116 Mangan, M., \& Sisson, T. (2000). Delayed, disequilibrium degassing in rhyolite magma: 1117 decompression experiments and implications for explosive volcanism. Earth and $1118 \quad$ Planetary Science Letters, 183(3-4), 441-455.

1119 Marsh, B. 1988. Crystal size distribution (CSD) in rocks and kinetics and dynamics of 1120 crystallization. Contributions to Mineralogy and Petrology, 99, 277-291.

1121 Martel, C. (2012). Eruption dynamics inferred from microlite crystallization experiments:

1122 application to Plinian and dome-forming eruptions of Mt. Pelée (Martinique, Lesser 1123 Antilles). Journal of Petrology, 53(4), 699-725.

1124 Martel, C., \& Iacono-Marziano, G. (2015). Timescales of bubble coalescence, outgassing, and 1125 foam collapse in decompressed rhyolitic melts. Earth and Planetary Science Letters, 412, $1126 \quad 173-185$.

1127 Martel, C., Pichavant, M., Bourdier, J. L., Traineau, H., Holtz, F., \& Scaillet, B. (1998). Magma 1128 storage conditions and control of eruption regime in silicic volcanoes: experimental 1129 evidence from Mt. Pelée. Earth and Planetary Science Letters, 156(1-2), 89-99.

1130 Marti, J., Castro, A., Rodriguez, C., Costa, F., Carrasquilla, S., Pedreira, R. \& Bolos, X. 2013. 1131 Correlation of Magma Evolution and Geophysical Monitoring during the 2011-2012 El 1132 Hierro (Canary Islands) Submarine Eruption. Journal of Petrology, 54, 1349-1373, doi: $1133 \quad 10.1093 /$ petrology/egt014. 
1134 Martí, J., Groppelli, G., \& da Silveira, A. B. (2018). Volcanic stratigraphy: a review. Journal of 1135 Volcanology and Geothermal Research, 357, 68-91.

1136 Mastin, L. G., Guffanti, M., Servranckx, R., Webley, P., Barsotti, S., Dean, K., Durant, A., Ewert, 1137 J. W., Neri, A., Rose, W. I., Schnieder, D., Siebert, L., Stunder, B., Swanson, G., Tupper, 1138 A., Volentik, A., \& Schneider, D. (2009). A multidisciplinary effort to assign realistic source parameters to models of volcanic ash-cloud transport and dispersion during eruptions. Journal of Volcanology and Geothermal Research, 186(1-2), 10-21.

1141 Matthews, N.E., Smith, V.C., Costa, A., Durant, A.J., Pyle, D.M., \& Pearce, J.G. (2012). Ultra1142 distal tephra deposits from super-eruptions: Examples from Toba, Indonesia and Taupo Volcanic Zone, New Zealand. Quaternary International 258:54-79. doi:

Meletlidis, S., Di Roberto, A., et al. 2012. Xenopumices from the 2011-2012 submarine eruption of El Hierro (Canary Islands, Spain): Constraints on the plumbing system and magma ascent. Geophysical Research Letters, 39, L17302, doi: 10.1029/2012GL052675. 10.1016/j.quaint.2011.07.010

1154 Metrich, N., Bertagnini, A. \& Di Muro, A. 2010. Conditions of Magma Storage, Degassing and

Meletlidis, S., Di Roberto, A., et al. 2015. New insight into the 2011-2012 unrest and eruption of El Hierro Island (Canary Islands) based on integrated geophysical, geodetical and petrological data. Annals of Geophysics, 58, doi: 10.4401/ag-6754.

Métrich, N., \& Wallace, P. J. (2008). Volatile abundances in basaltic magmas and their degassing paths tracked by melt inclusions. Reviews in mineralogy and geochemistry, 69(1), 363402. Ascent at Stromboli: New Insights into the Volcano Plumbing System with Inferences on the Eruptive Dynamics. Journal of Petrology, 51, 603-626, doi: 10.1093/petrology/egp083. 
1157 Mollo, S., Giacomoni, P.P., Coltorti-M, Ferlito, C., Iezzi, G. \& Scarlato, P. 2015. Reconstruction

1158 of magmatic variables governing recent Etnean eruptions: Constraints from mineral

1159 chemistry and P-T-fO(2)-H2O modeling. Lithos, 212, 311-320, doi:

$1160 \quad$ 10.1016/j.lithos.2014.11.020.

1161 Moore, G. (2008). Interpreting $\mathrm{H} 2 \mathrm{O}$ and $\mathrm{CO} 2$ contents in melt inclusions: constraints from 1162 solubility experiments and modeling. Reviews in Mineralogy and Geochemistry, 69(1), $1163 \quad 333-362$

1164 Moretti, R., Papale, P., \& Ottonello, G. (2003). A model for the saturation of COHS fluids in 1165 silicate melts. Geological Society, London, Special Publications, 213(1), 81-101.

1166 Morgan, D., Jerram, D., Chertkoff, D., Davidson, J., Pearson, D., Kronz, A. \& Nowell, G. 2007 a. 1167 Combining CSD and isotopic microanalysis: Magma supply and mixing processes at 1168 Stromboli Volcano, Aeolian Islands, Italy. Earth and Planetary Science Letters, 260, 4191169431.

1170 Morgan, D.J., Jerram, D.A., Chertkoff, D.G., Davidson, J.P., Pearson, D.G., Kronz, A. \& Nowell, 1171 G.M. 2007b. Combining CSD and isotopic microanalysis: Magma supply and mixing 1172 processes at Stromboli Volcano, Aeolian Islands, Italy. Earth and Planetary Science 1173 Letters, 260, 419-431, doi: 10.1016/j.epsl.2007.05.037.

1174 Mourtada-Bonnefoi, C. C., \& Laporte, D. (2004). Kinetics of bubble nucleation in a rhyolitic 1175 melt: an experimental study of the effect of ascent rate. Earth and Planetary Science $1176 \quad$ Letters, 218(3-4), 521-537.

1177 Németh, K., \& Cronin, S. J. (2007). Syn-and post-eruptive erosion, gully formation, and 1178 morphological evolution of a tephra ring in tropical climate erupted in 1913 in West 1179 Ambrym, Vanuatu. Geomorphology, 86(1-2), 115-130. 
1180 Newhall, C. G., \& Self, S. (1982). The volcanic explosivity index (VEI) an estimate of explosive 1181 magnitude for historical volcanism. Journal of Geophysical Research: Oceans, 87(C2), $1182 \quad 1231-1238$

1183 Newhall, C., \& Hoblitt, R. (2002). Constructing event trees for volcanic crises. Bulletin of $1184 \quad$ Volcanology, 64(1), 3-20.

1185 Newman, S., \& Lowenstern, J. B. (2002). VolatileCalc: a silicate melt-H2O-CO2 solution 1186 model written in Visual Basic for excel. Computers \& Geosciences, 28(5), 597-604.

1187 Nielsen, R. L., Michael, P. J., \& Sours-Page, R. (1998). Chemical and physical indicators of 1188 compromised melt inclusions. Geochimica et Cosmochimica Acta, 62(5), 831-839.

1189 O'Hara, M. \& Herzberg, C. 2002. Interpretation of trace element and isotope features of basalts: 1190 Relevance of field relations, petrology, major element data, phase equilibria, and magma 1191 chamber modeling in basalt petrogenesis. 66, 2167-2191.

1192 Oppenheimer, C., Scaillet, B., \& Martin, R. S. (2011). Sulfur degassing from volcanoes: source 1193 conditions, surveillance, plume chemistry and earth system impacts. Reviews in $1194 \quad$ Mineralogy and Geochemistry, 73(1), 363-421.

1195 Pamukcu, A. S., Gualda, G. A., Bégué, F., \& Gravley, D. M. (2015). Melt inclusion shapes: 1196 Timekeepers of short-lived giant magma bodies. Geology, 43(11), 947-950.

1197 Papale, P. (2005). Determination of total $\mathrm{H} 2 \mathrm{O}$ and $\mathrm{CO} 2$ budgets in evolving magmas from melt 1198 inclusion data. Journal of Geophysical Research: Solid Earth, 110(B3).

1199 Papale, P., Moretti, R., \& Barbato, D. (2006). The compositional dependence of the saturation 1200 surface of $\mathrm{H} 2 \mathrm{O}+\mathrm{CO} 2$ fluids in silicate melts. Chemical Geology, 229(1-3), 78-95.

1201 Parat, F., \& Holtz, F. (2005). Sulfur partition coefficient between apatite and rhyolite: the role of 1202 bulk S content. Contributions to Mineralogy and Petrology, 150(6), 643-651. 
1203 Peltier, A., Bachèlery, P. \& Staudacher, T. 2009. Magma transport and storage at Piton de La 1204 Fournaise (La Réunion) between 1972 and 2007: A review of geophysical and geochemical data. Journal of Volcanology and Geothermal Research, 184, 93-108, doi:

\section{7}

1208

1209

1210

1212

1213

1214

1215

1217

1218

1219

1220

1221

1222

1223 10.1016/j.jvolgeores.2008.12.008.

Perugini, D., De Campos, C. P., Dingwell, D. B., Petrelli, M., \& Poli, G. (2008). Trace element mobility during magma mixing: preliminary experimental results. Chemical Geology, 256(3-4), 146-157.

Petrone, C.M., Bugatti, G., Braschi, E., Tommasini, S., 2016. Pre-eruptive magmatic processes re-timed using a non-isothermal approach to magma chamber dynamics. Nature Communications 7, 12946. doi:10.2138/am-1998-9-1022

Pfeiffer, T., Costa, A., \& Macedonio, G. (2005). A model for the numerical simulation of tephra fall deposits. Journal of Volcanology and Geothermal Research, 140(4), 273-294.

Pichavant, M., Di Carlo, I., Le Gac, Y., Rotolo, S.G. \& Scaillet, B. 2009. Experimental Constraints on the Deep Magma Feeding System at Stromboli Volcano, Italy. Journal of Petrology, 50, 601-624, doi: 10.1093/petrology/egp014.

Pichavant, M., Di Carlo, I., Rotolo, S. G., Scaillet, B., Burgisser, A., Le Gall, N., \& Martel, C. (2013). Generation of CO 2-rich melts during basalt magma ascent and degassing. Contributions to Mineralogy and Petrology, 166(2), 545-561.

Pichavant, M., Martel, C., Bourdier, J. L., \& Scaillet, B. (2002). Physical conditions, structure, and dynamics of a zoned magma chamber: Mount Pelée (Martinique, Lesser Antilles Arc). Journal of Geophysical Research: Solid Earth, 107(B5), ECV-1. 
1224 Pichavant, M., Mysen, B. \& Macdonald, R. 2002. Source and H2O content of high-MgO magmas in island arc settings: an experimental study of a primitive calc-alkaline basalt from St. Vincent, Lesser Antilles arc. 66, 2193-2209.

1227 Pichavant, M., Pompilio, M., D oriano, C. \& Dicarlo, I. 2011. Petrography, mineralogy and geochemistry of a primitive pumice from Stromboli: implications for the deep feeding system. European Journal of Mineralogy, 23, 499-517, doi: 10.1127/0935-

1231 Pichavant, M., Scaillet, B., Pommier, A., Iacono-Marziano, G., \& Cioni, R. (2014). Nature and 1232 evolution of primitive Vesuvius magmas: an experimental study. Journal of Petrology,

1234 Pietruszka, A.J., Heaton, D.E., Marske, J.P. \& Garcia, M.O. 2015. Two magma bodies beneath the summit of Kîlauea Volcano unveiled by isotopically distinct melt deliveries from the mantle. Earth and Planetary Science Letters, 413, 90-100, doi: 10.1016/j.epsl.2014.12.040.

1237 Pistolesi M, Rosi M, Cioni R, Cashman, K. V., Rossotti, A., Aguilera, E. (2011) Physical 1238 volcanology of the post--twelfth-century activity at Cotopaxi volcano, Ecuador: Behavior 1239

1241 Pistolesi, M., Bertagnini, A., Di Roberto, A., Isaia, R., Vona, A., Cioni, R., \& Giordano, G. (2017). The Baia-Fondi di Baia eruption at Campi Flegrei: Stratigraphy and dynamics of a multistage caldera reactivation event. Bulletin of Volcanology, 79(9), 67.

1244 Pistolesi, M., Cioni, R., Bonadonna, C., Elissondo, M., Baumann, V., Bertagnini, A., Chiari, L., 1245 Gonzales, R., Rosi, M., \& Francalanci, L. (2015). Complex dynamics of small-moderate 
volcanic events: the example of the 2011 rhyolitic Cordón Caulle eruption, Chile. Bulletin of Volcanology, 77(1), 3.

1248 Pistolesi, M., Cioni, R., Francalanci, L., Bertagnini, A., D'Oriano, C., Braschi, E., \& Höskuldsson, 1249 Á. (2016). The onset of an eruption: selective assimilation of hydrothermal minerals during pre-eruptive magma ascent of the 2010 summit eruption of Eyjafjallajökull volcano, Iceland. Journal of Volcanology and Geothermal Research 327, 449-458. doi:10.1016/j.jvolgeores.2016.09.011

1253 Pommier, A., Gaillard, F., Malki, M., \& Pichavant, M. (2010). Methodological re-evaluation of 1254 the electrical conductivity of silicate melts. American Mineralogist, 95(2-3), 284-291.

1255 Pommier, A., Gaillard, F., Pichavant, M., \& Scaillet, B. (2008). Laboratory measurements of 1256 electrical conductivities of hydrous and dry Mount Vesuvius melts under pressure. Journal of Geophysical Research: Solid Earth, 113(B5).

1258 Pompilio, M., Bertagnini, A. \& Métrich, N. 2011. Geochemical heterogeneities and dynamics of 1259 1260 1261 1262 1263 1264 05065-X. magmas within the plumbing system of a persistently active volcano: evidence from Stromboli. Bulletin of Volcanology, 74, 881-894, doi: 10.1007/s00445-011-0571-z.

Pompilio, M., Bertagnini, A., del Carlo, P. \& Di Roberto, A. 2017. Magma dynamics within a basaltic conduit revealed by textural and compositional features of erupted ash: the December 2015 Mt. Etna paroxysms. Scientific Reports, 7, 10, doi: 10.1038/s41598-017-

1265 Proussevitch, A., Sahagian, D. \& Carlson, W. 2007. Statistical analysis of bubble and crystal size 1266 distributions: Application to Colorado Plateau basalts. Journal of Volcanology and 1267 Geothermal Research, 164, 112-126. 
1268 Putirka, K. (2016). Amphibole thermometers and barometers for igneous systems and some 1269 implications for eruption mechanisms of felsic magmas at arc volcanoes. American

$1270 \quad$ Mineralogist, 101(4), 841-858.

1271 Putirka, K. 1997. Magma transport at Hawaii: Inferences based on igneous thermobarometry. $1272 \quad$ Geology, 25, 69-72.

1273 Pyle, D. M. (2015). Sizes of volcanic eruptions. In The encyclopedia of volcanoes (pp. 257-264). $1274 \quad$ Academic Press.

1275 Pyle, D.M., Ricketts, G.D., Margari, V., van Andel, T.H., Sinitsyn, A.A., Praslov, N.D., \& 1276 Lisitsyn, S. (2006). Wide dispersal and deposition of distal tephra during the Pleistocene “Campanian Ignimbrite/Y5” eruption, Italy. Quaternary Science Reviews 25, 2713-2728. doi:10.1016/j.quascirev.2006.06.008

Ridolfi, F., Renzulli, A., \& Puerini, M. (2010). Stability and chemical equilibrium of amphibole 1280 in calc-alkaline magmas: an overview, new thermobarometric formulations and application to subduction-related volcanoes. Contributions to Mineralogy and Petrology,

1283 Roedder, E. (1979). Origin and significance of magmatic inclusions. Bulletin de Mineralogie, 1284 $102(5), 487-510$.

1285 Rossi, S., Petrelli, M., Morgavi, D., González-García, D., Fischer, L. A., Vetere, F., \& Perugini, 1286 1287 1288 D. (2017). Exponential decay of concentration variance during magma mixing: Robustness of a volcanic chronometer and implications for the homogenization of chemical heterogeneities in magmatic systems. Lithos, 286, 396-407.

Rutherford, M. J. (2008). Magma ascent rates. Reviews in Mineralogy and Geochemistry, 69(1), 241-271. 
1291 Rutherford, M. J., Sigurdsson, H., Carey, S., \& Davis, A. (1985). The May 18, 1980, eruption of Mount St. Helens: 1. Melt composition and experimental phase equilibria. Journal of Geophysical Research: Solid Earth, 90(B4), 2929-2947.

1294 Salisbury, M.J., Bohrson, W.A., Clynne, M.A., Ramos, F.C. \& Hoskin, P. 2008. Multiple

Santacroce, R., Cioni, R., Marianelli, P., Sbrana, A., Sulpizio, R., Zanchetta, G., Donahue, D. J., Plagioclase Crystal Populations Identified by Crystal Size Distribution and in situ Chemical Data: Implications for Timescales of Magma Chamber Processes Associated with the 1915 Eruption of Lassen Peak, CA. Journal of Petrology, 49, 1755-1780, doi: 10.1093/petrology/egn045. \& Joron, J. L. (2008). Age and whole rock-glass compositions of proximal pyroclastics from the major explosive eruptions of Somma-Vesuvius: A review as a tool for distal tephrostratigraphy. Journal of Volcanology and Geothermal Research, 177(1), 1-18.

Saunders, K., Blundy, J., Dohmen, R. \& Cashman, K. 2012. Linking Petrology and Seismology at an Active Volcano. Science, 336, 1023-1027, doi: 10.1126/science.1220066.

Scaillet, B., \& Evans, B. W. (1999). The 15 June 1991 eruption of Mount Pinatubo. I. Phase equilibria and pre-eruption $\mathrm{P}-\mathrm{T}-\mathrm{f} \mathrm{O} 2-\mathrm{f} \mathrm{H} 2 \mathrm{O}$ conditions of the dacite magma. Journal of Petrology, 40(3), 381-411.

Scaillet, B., \& Pichavant, M. (2003). Experimental constraints on volatile abundances in arc magmas and their implications for degassing processes. Geological Society, London, Special Publications, 213(1), 23-52.

Scaillet, B., Pichavant, M., \& Cioni, R. (2008). Upward migration of Vesuvius magma chamber over the past 20,000 years. Nature, 455(7210), 216 
1313 Scandone, R., Cashman, K.V. \& Malone, S.D. 2007. Magma supply, magma ascent and the style 1314 of volcanic eruptions. Earth and Planetary Science Letters, 253, 513-529, doi: $1315 \quad$ 10.1016/j.epsl.2006.11.016.

1316 Schiano, P. 2003. Primitive mantle magmas recorded as silicate melt inclusions in igneous 1317 minerals. Earth Science Reviews, 63, 121-144, doi: 10.1016/S0012-8252(03)00034-5.

1318 Schiavi, F., Kobayashi, K., Moriguti, T., Nakamura, E., Pompilio, M., Tiepolo, M. \& Vannucci, 1319 R. 2010. Degassing, crystallization and eruption dynamics at Stromboli: trace element and 1320 lithium isotopic evidence from 2003 ashes. Contributions to Mineralogy and Petrology, $1321 \quad 159,541-561$.

1322 Schiavi, F., Tiepolo, M., Pompilio, M. \& Vannucci, R. 2006. Tracking magma dynamics by Laser 1323 Ablation (LA)-ICPMS trace element analysis of glass in volcanic ash: the 1995 activity of 1324 Mt. Etna. Geophysical Research Letters, 33, 10.1029/2005GL024789.

1325 Schuth, S., Rohrbach, A., Munker, C., Ballhaus, C., Garbe-Schonberg, D. \& Qopoto, C. 2004. 1326 Geochemical constraints on the petrogenesis of arc picrites and basalts, New Georgia 1328 Shishkina, T. A., Botcharnikov, R. E., Holtz, F., Almeev, R. R., Jazwa, A. M., \& Jakubiak, A. A. 1329 (2014). Compositional and pressure effects on the solubility of $\mathrm{H} 2 \mathrm{O}$ and $\mathrm{CO} 2$ in mafic 1330 melts. Chemical Geology, 388, 112-129.

1331 Simkin, T., Siebert, L., McClelland, L., Bridge, D., Newhall, C. and Latter, J.H., 1981. Volcanoes 1332 of the world: a regional directory, gazetteer, and chronology of volcanism during the last 133310,000 years. US Hutchinson Ross Publishing. 
1334 Smith, D. \& Leeman, W. 2005. Chromian spinel-olivine phase chemistry and the origin of primitive basalts of the southern Washington Cascades. Journal of Volcanology and Geothermal Research, 140, 49-66.

1337 Sparks, S. R., Sigurdsson, H., \& Wilson, L. (1977). Magma mixing: a mechanism for triggering $1338 \quad$ acid explosive eruptions. Nature, 267(5609), 315.

1339 Spilliaert N, Allard P, Metrich N, Sobolev AV (2006) Melt inclusion record of the conditions of ascent, degassing, and extrusion of volatile-rich alkali basalt during the powerful 2002

Streck, M.J., Leeman, W.P. \& Chesley, J. 2007. High-magnesian andesite from Mount Shasta: A product of magma mixing and contamination, not a primitive mantle melt. Geology, 35, flank eruption of Mount Etna (Italy). J Geophys Res 111:B04203. doi:

$$
10.1029 / 2005 J B 003934
$$
351, doi: 10.1130/G23286A.1.

Sulpizio, R., Cioni, R., Di Vito, M.A., Mele, D., Bonasia, R., \& Dellino, P. (2010). The Pomici di Avellino eruption of Somma-Vesuvius (3.9 ka bp). Part I: stratigraphy, compositional variability and eruptive dynamics. Bull Volcanol 72, 539-558. doi:10.1007/s00445-0090339-X

Symonds, R. B., Gerlach, T. M., \& Reed, M. H. (2001). Magmatic gas scrubbing: implications for volcano monitoring. Journal of Volcanology and Geothermal Research, 108(1-4),

1353 Taddeucci, J., Pompilio, M. \& Scarlato, P. 2004. Conduit processes during the July-August 2001 1354 explosive activity of Mt. Etna (Italy): inferences from glass chemistry and crystal size distribution of ash particles. Journal of Volcanology and Geothermal Research, 137, 331356 54. 
1357 Thordarson et al. 2009

1358 Thouret, J. C. (1999). Volcanic geomorphology—an overview. Earth-science reviews, 47(1-2), $1359 \quad 95-131$.

1360 Tibaldi, A., Corazzato, C., Apuani, T., \& Cancelli, A. (2003). Deformation at Stromboli volcano 1361 (Italy) revealed by rock mechanics and structural geology. Tectonophysics, 361(3-4), 187204.

1363 Todde, A., Cioni, R., Pistolesi, M., Geshi, N., \& Bonadonna, C. (2017). The 1914 Taisho eruption 1364 of Sakurajima volcano: stratigraphy and dynamics of the largest explosive event in 1365 Japanduring the twentieth century 1-22. doi:10.1007/s00445-017-1154-4

1366 Tomiya-A \& Takahashi, E. 1995. Reconstruction of an Evolving Magma Chamber beneath Usu 1367 Volcano since the 1663 Eruption. Journal of Petrology, 36, 617-636, doi: $1368 \quad 10.1093 /$ petrology/36.3.617.

1369 Tommasini, S., Avanzinelli, R. \& Francalanci, L. 2007. The fate of high-angle dipping slabs in the 1370 subduction factory: An integrated trace element and radiogenic isotope ( $\mathrm{U}, \mathrm{Th}, \mathrm{Sr}, \mathrm{Nd}, \mathrm{Pb})$ study of Stromboli volcano, Aeolian Arc, Italy. Journal of Petrology, 48, 2407-2430.

1372 Tonarini, S., Armienti, P., D'Orazio, M. \& Innocenti, F. 2001. Subduction-like fluids in the genesis 1373 1374

1375 Troll, V.R., Klugel, A., et al. 2012. Floating stones off El Hierro, Canary Islands: xenoliths of pre1376 island sedimentary origin in the early products of the October 2011 eruption. Solid Earth, 1377 3, 97-110, doi: 10.5194/se-3-97-2012.

1378 Ubide, T. \& Kamber, B.S. 2018. Volcanic crystals as time capsules of eruption history. Nature 1379 Communications, 9, 1-12, doi: 10.1038/s41467-017-02274-w. 
1380 Vasseur, J., Wadsworth, F. B., \& Dingwell, D. B. (2018). Predicting multiphase magma failure 1381 at the laboratory scale using acoustic emission data. Frontiers in Earth Science, 6, 132.

1382 Vetere, F., Botcharnikov, R. E., Holtz, F., Behrens, H., \& De Rosa, R. (2011). Solubility of H2O 1383 and $\mathrm{CO} 2$ in shoshonitic melts at $1250 \mathrm{C}$ and pressures from 50 to $400 \mathrm{MPa}$ : implications 1384 for Campi Flegrei magmatic systems. Journal of Volcanology and Geothermal Research, $1385 \quad 202(3-4), 251-261$.

1386 Wallace, P. J., Anderson Jr, A. T., \& Davis, A. M. (1995). Quantification of pre-eruptive 1387 exsolved gas contents in silicic magmas. Nature, 377(6550), 612.

1388 Waters, L. E., \& Lange, R. A. (2015). An updated calibration of the plagioclase-liquid 1389 hygrometer-thermometer applicable to basalts through rhyolites. American Mineralogist, $1390 \quad 100(10), 2172-2184$.

1391 Watson, E. B. (1994). Diffusion in volatile-bearing magmas. Reviews in Mineralogy and 1392 Geochemistry, 30(1), 371-411.

1393 Webster, J. D., \& Piccoli, P. M. (2015). Magmatic apatite: A powerful, yet deceptive, mineral. $1394 \quad$ Elements, 11(3), 177-182.

1395 Wilson, B. M. (2007). Igneous petrogenesis a global tectonic approach. Springer Science \& $1396 \quad$ Business Media.

1397 Wright, T.L. \& Klein, F.W. 2006. Deep magma transport at Kilauea volcano, Hawaii. Lithos, 87, $1398 \quad$ 50-79, doi: 10.1016/j.lithos.2005.05.004.

1399 Wyllie, P. J., Carroll, M. R., Johnston, A. D., Rutter, M. J., Sekine, T., \& Van der Laan, S. R. 1400 (1989). Interactions among magmas and rocks in subduction zone regions: experimental 1401 studies from slab to mantle to crust. European Journal of Mineralogy, 1(2), 165-179. 
1402 Zellmer, G.F., Blake, S., Vance, D., Hawkesworth, C. \& Turner, S. 1999. Plagioclase residence 1403 times at two island arc volcanoes (Kameni Islands, Santorini, and Soufriere, St. Vincent) 1404 determined by Sr diffusion systematics. Contributions to Mineralogy and Petrology, 136, $1405 \quad 345-357$, doi: $10.1007 / \mathrm{s} 004100050543$.

1406 Zellmer, G.F., Sparks, R.S.J., Hawkesworth, C.J. \& Wiedenbeck, M. 2003. Magma Emplacement 1407 and Remobilization Timescales Beneath Montserrat: Insights from Sr and Ba Zonation in 1408 Plagioclase Phenocrysts. Journal of Petrology, 44, 1413-1431, doi: $1409 \quad 10.1093 /$ petrology/44.8.1413.

1410 Zieg, M. \& Marsh, B. 2002. Crystal size distributions and scaling laws in the quantification of 1411 igneous textures. Journal of Petrology, 43, 85-101.

\section{Figure captions}

1414 Fig. 1 Idealized view of a magmatic system of a volcano. Right side shows the main 1415 methodologies usually employed for the study of the different portions of the plumbing system 1416 and associated limits (dotted line).

1418 Fig. 2 Reconstructing the stratigraphy of the deposits at the scale of an entire volcanic 1419 edifice is a basilar step to understand the evolution of that volcano and to start a detailed mapping 1420 of the area. A) On the southern sector of Cotopaxi volcano, the main steep gullies (barrancas) show

1421 the whole stratigraphic sequence of deposits emplaced during the last 5 ka consisting of an 1422 alternation of tephra and lava deposits. B) The merging of multiple sections, on the other hand, 1423 allowed a detailed reconstruction of the last 800 years of activity at Cotopaxi (Pistolesi et al., 1424 2011). A synthetic stratigraphic log highlights the complexity and the large variability of the 
1425 eruptive dynamics which led to the emplacement of lapilli and ash layers intercalated to scoria1426 flow deposits.

Fig. 3 In order to reconstruct the compositional variability of the erupted products, it is 1429 always important to discuss both the variability at the scale of a single eruption (or eruptive cycle) 1430 and the time-related changes in magma composition. The last 22 ka of activity at Somma-Vesuvius

1431 show a clear trend of increasing alkalinity with time, and large compositional variability of the 1432 magma erupted during single eruptions or during short eruptive cycles. The data can be discussed 1433 in terms of source-related changes in the magma feeding the shallow reservoirs, and of different 1434 processes and physico-chemical conditions of crystallization, refilling and assimilation/fluid 1435 exchange in these reservoirs (data from Santacroce et al., 2008).

Fig. 4 Detailed geochronological reconstructions of the activity of a volcano reveal the 1438 temporal trends of volcanic activity and are important to define the expected time scale for volcanic 1439 reactivation. A) The schematic chronogram of Cotopaxi activity during the last 2000 yr B.P. 1440 clearly shows the presence of eruption clusters (with no obvious intervening soils) separated by 1441 long periods during which only a few large eruptions occur (Barberi et al., 1995; Pistolesi et al., 1442 2011). These two contrasting behaviors of the volcano over the past 2000 yrs were also observed 1443 in the eruption pattern of the past 800 yrs of activity. During the period A.D. 1150-1742, the 1444 average magma eruption rate was low, and activity consisted of isolated explosive eruptions, while 1445 during the period A.D. 1742-1880, the average magma eruption rate was higher, and activity was 1446 dominated by numerous explosive events separated by eruptive pauses that lasted from a few years 1447 to a few decades (eruption cluster). The eighteenth- to nineteenth-century cluster started with 
1448 Plinian outbursts (A.D. 1742-1744), followed by very high intensity and magnitude Plinian bursts 1449 (A.D. 1766-1768). These large events were eventually followed by a period of long-lasting, 1450 moderate-intensity magma degassing mixed with staggered, low- intensity and low-magnitude 1451 explosive bursts, each dominated by a short-lived sub Plinian/violent Strombolian phase followed

1452 by boiling-over activity and associated scoria flows. B). The chronogram of the last $22 \mathrm{ka}$ of 1453 activity Mt. Somma-Vesuvius volcano shows a different behavior with respect to Cotopaxi. 1454 Activity is characterized by a number of large eruptions (Plinian and subplinian) separated by 1455 repose times whose duration varies with age. In fact, while the activity between 22 and 4 ka ago 1456 was mainly characterized by episodic events of large intensity (and magnitude; Cioni et al., 2008) 1457 separated by progressively decreasing repose times, in the last 4000 years the activity became more 1458 and more frequent. The increase in frequency of the eruptions coincided with a general decrease 1459 of their intensity (and magnitude). These changes are clearly associated with changes in magma 1460 composition. Accurate geological reconstructions suggest that the observed lower frequency in the 1461 oldest activity is real and not related to an incomplete geological record, although the problem of 1462 incompleteness in the geological record should always be discussed in detail.

1464 Fig. 5 The detailed, multiparametric reconstruction of a complex eruptive sequence is the 1465 key to the definition of the main eruptive processes which controlled past eruption, and can be 1466 used to define the range of eruption scenarios characterizing a given volcano. The Baia-Fondi di 1467 Baia eruption (9525-9696 BP) is one of the sporadic events that have occurred in the western 1468 sector of the Campi Flegrei caldera and opened Epoch 2 of the caldera activity after a 1000-year1469 long period of quiescence. Although relatively small in terms of erupted volume with respect to 1470 most of the events of the past $15 \mathrm{ka}$, the Baia-Fondi di Baia eruption was characterized by a 
1471 complex series of events, which were reconstructed based on a detailed stratigraphic study

1472 (Pistolesi et al., 2017). The idealized composite stratigraphy of the different phases of the eruption

1473 shows how sedimentological data (grains-size and componentry) concur in identifying different

1474 eruptive locations and emplacement dynamics (on-land vs. shallow water vent, fall-out vs. PDC

1475 deposits). Bulk density $\left(\mathrm{gcm}^{-3}\right)$, vesicularity (vol.\%), Vesicle Number Density $\left(\mathrm{cm}^{-3}\right)$, and 1476 decompression rate $\left(\mathrm{MPas}^{-1}\right)$ data linked to variations in $\mathrm{SiO}_{2}, \mathrm{CaO}$, and $\mathrm{K}_{2} \mathrm{O}$ (wt.\%) contents

1477 further indicate different types of juvenile material (e.g. variable conditions during ascent in the 1478 conduit) as well as variable magma sources involved in the eruption.

Fig. 6 Simplified interpretative model of the plumbing system of Stromboli (modified by

1481 Métrich et al, 2011) based on (1) the melt compositions and melt saturation pressures recorded by

1482 sealed melt inclusions and unsealed embayments trapped during olivine crystallization, (2) the

1483 crystal textures and (3) the chemistry of Stromboli pumice and scoria samples. LP and HP refer to

1484 low- and high-porphyritic magmas, respectively, according to Francalanci et al. (2004).

1485

Fig. 7 (a) Example of a simplified system analysis of the zoning patterns recorded in olivine 1487 crystals of 1991-1993 Etna eruption. Each box represents a magmatic reservoir of different 1488 composition identified by the overall core plateau compositions and zoning patterns. M0, M1 and 1489 M2 represent end member reservoirs whereas $\mathrm{mml}$ is a reservoir of mixing. The colored lines 1490 represent the zoning patterns recorded in single olivine crystals. The arrows indicate the direction 1491 of the zonings from core to rim (see details in the original paper). (b) Information distilled from 1492 (a) to highlight the three main magma pathways M0-M1-mm1 (light gray bar) M1-mm1 (dark 1493 gray bar) and M2- mm1 (black bar). (c) An example of a physical plumbing system that is 
1494 consistent with (a) and (b). Black dotted lines mark the preferred path followed by many crystals.

1495 Various timescales $(\Delta \mathrm{t} 1, \Delta \mathrm{t} 2$ and $\Delta \mathrm{t} 3)$ that can be extracted from kinetic modeling relate to 1496 duration of residence of melts in different segments of the plumbing system, as shown here. From 1497 Kahl et al. (2011).

Fig. 8 Phase equilibria of Vesuvius phonolites (Scaillet et al., 2008) showing pre-eruptive 1500 conditions inferred for the AD 79 Pompei and AD 472 Pollena events. The top panels show the 1501 isobaric-polythermal phase relationships at $200 \mathrm{MPa}$ (2 kbar) for the two compositions as a 1502 function of temperature and fluid composition, here expressed as the mole fraction of water $1503\left(\mathrm{XH}_{2} \mathrm{Ofluid}\right)$. The bottom panels show the polybaric-isothermal sections as a function also of $1504 \mathrm{XH}_{2} \mathrm{Ofluid}$. For the isobaric sections, the correspondence with dissolved melt water content $1505\left(\mathrm{H}_{2} \mathrm{Omelt}\right)$ is given on the horizontal axis. All sections have been established at an $\mathrm{fO}_{2}$ one $\log$ unit 1506 above the $\mathrm{Ni}-\mathrm{NiO}$ transition $(\mathrm{NNO}+1)$. Black squares represent experimental charges. The stability 1507 fields of the main phases are labelled with mineral acronyms lying inside the corresponding 1508 stability field. The dashed line represents the volume proportion of crystals at $10 \%$. The infered 1509 pre-eruptive conditions are indicated by the red filled box and corresponds to the $\mathrm{T}-\mathrm{XH}_{2} \mathrm{Ofluid}$ 1510 locus where the phenocryst assemblage observed in the pumices is experimentally reproduced. 1511 The green rectangle gives the melt water content inferred from the analyses of melt inclusions in 1512 phenocrysts (Cioni, 2000). For the Pompeii eruption, it is possible to reproduce the phenocrysts 1513 proportion and assemblage at $200 \mathrm{MPa}$, whereas for the Pollena event this is possible only at 100 1514 MPa. This shows that the level of magma accumulation beneath Vesuvius shifted from $200 \mathrm{MPa}$ 1515 up to $100 \mathrm{MPa}$, or about $3 \mathrm{~km}$ depth less, in less than 400 years. Acronyms for phases are as 
1516 follows: Feld: feldspar, Leuc: leucite; Scap: scapolite; Neph: nepheline; Cpx: clinopyroxene; Gt:

1517 garnet; Amph: amphibole, Sod: sodalite.

Fig. 9. a) The contrasted solubilities of $\mathrm{H}_{2} \mathrm{O}$ and $\mathrm{CO}_{2}$ in shoshonite melts from Campi Flegrei

1520 volcano (Vetere et al. 2011). The solid lines represent isobars. The dashed lines are isopleths of 1521 constant fluid composition for the melts saturated with $\mathrm{H}_{2} \mathrm{O}-\mathrm{CO}_{2}$-bearing flluids. The various 1522 symbols indicate the pressure (in MPa) at which the solubility experiments (symbols with attached 1523 errors) were done with either pure $\mathrm{H}_{2} \mathrm{O}$ (horizontal axis) or mixed $\mathrm{H}_{2} \mathrm{O}-\mathrm{CO}_{2}$ fluids. Note the 1524 contrasted solubilities of water ( $\mathrm{wt} \%)$ and $\mathrm{CO}_{2}(\mathrm{ppm})$. b) Simulation of gas composition during 1525 the ascent of a rhyolitic magma (Burgisser and Scaillet, 2007). This type of simulation uses the 1526 solubility laws for the volatile species present in the system, in the example shown $\mathrm{H}_{2} \mathrm{O}, \mathrm{H}_{2}, \mathrm{SO}_{2}$, $1527 \mathrm{H}_{2} \mathrm{~S}, \mathrm{~S}_{2}$. The simulations show the variation of $\mathrm{H}_{2} \mathrm{~S} / \mathrm{SO}_{2}$ ratio in the gas phase of an ascending 1528 rhyolitic magmas (initially lying at 2000 bar) for various starting conditions in terms of redox state 1529 (here expressed as dNNO) and amount of fluid phase initially presents in the reservoir. The vertical 1530 black rectangle indicates the measured $\mathrm{H}_{2} \mathrm{O} / \mathrm{SO}_{2}$ ratio of actual volcanic gases at silicic volcanoes, 1531 showing that the simulation broadly captures the first order chemical patterns expressed by 1532 volcanic gases.

Fig. 10 Image of experimentally mixed magmas under either dry or hydrous conditions 1535 (Laumonier et al., 2014). All experiments were performed at $300 \mathrm{MPa}$ but at different temperatures 1536 depending on the dry or hydrous character of the system, as indicated on the figure. In both dry 1537 and hydrous conditions, the transition between no mixing (left panels) and onset of mixing (right 1538 panels) occurs over a very short temperature interval (about $10-15^{\circ} \mathrm{C}$ ) and is related to the slight 
1539 change in crystal proportion that controls the viscosity of the mafic end-member (basalt

1540 composition, always lying at the bottom). The overlying felsic end member is a crystal-free dacite

1541 melt. Note that prior to the onset of mixing the boundary between the two end-members remains

1542 sharp and straight, while when mixing starts a crenulate interface develops with production of

1543 enclaves (right down panel) that may in turn disaggregate as deformation proceeds (top right

1544 panel). For each run, the amount of finite deformation applied to the sample is given $(\gamma)$. Run

1545 durations are on the order of a few hours each.

Fig. 11 The conditions favoring magma mixing at $200 \mathrm{MPa}$. The different panels show the

1548 evolution of the viscosities of the mafic-felsic magmas being juxtaposed depending on fraction of 1549 mafic magma injected into the felsic reservoir (Laumonier et al., 2014). The starting temperature 1550 of each magma is given (figures color-coded with viscosity trends). Felsic magmas are all water 1551 saturated while the basalt may be either dry $\left(1145^{\circ} \mathrm{C}\right)$ or $\mathrm{H}_{2} \mathrm{O}$-saturated $\left(980^{\circ} \mathrm{C}\right)$. In each panel, 1552 optimum mixing conditions are reached when the two viscosity curves cross-over. The vertical 1553 thick grey lines give the proportion of the mafic magma needed to achieve conditions favorable to 1554 mixing as well as the temperature of the homogeneous mixture so produced. The $\mathrm{SiO} 2$ content of 1555 that mixture is given on the horizontal top axis of each panel. Numbers labelling each curves give 1556 the crystal fraction in each end-member (the $\mathrm{r}$ parameter is the average axial ratio of crystals, which 1557 controls the bulk viscosity, see Laumonier et al. (2014)). In every case, the proportion of crystals 1558 increases in the mafic component, while it decreases in the felsic one, the latter ending almost 1559 always crystal-free by the time mixing is possible (vertical grey lines). For instance, the production 1560 of a homogeneous andesitic magma by mixing a hydrous basalt at $980^{\circ} \mathrm{C}$ with a rhyolite at $780^{\circ} \mathrm{C}$ 1561 (panel F), requires the injection of $76 \mathrm{wt} \%$ basalt into the rhyolitic reservoir. This ends-up 
1562 producing an andesite mixture with $57 \mathrm{wt} \% \mathrm{SiO}_{2}$ at a temperature of $934^{\circ} \mathrm{C}$. In general, when the 1563 composition of two end-members mixed strongly differ from each other (ie basalt with rhyolite), 1564 the proportion of mafic magma is about $70 \mathrm{wt} \%$ (to achieve equal viscosities).

Fig. 12 The effect of decompression on the volatile contents of silicate melts. The figure 1567 shows the measured $\mathrm{H}_{2} \mathrm{O}$ and $\mathrm{CO}_{2}$ contents of basaltic glasses (using a basalt from Stromboli as 1568 starting material) obtained in decompression experiments simulating magma ascent at Stromboli 1569 (Pichavant et al., 2013). The circles represent the starting conditions of each experiment in terms 1570 of volatile content. The oblique thin continuous lines are the isobaric $\mathrm{H}_{2} \mathrm{O}-\mathrm{CO}_{2}$ contents, calculated 1571 using the model of Papale et al. (2006). Squares show the volatile contents of glasses measured 1572 after decompression and quenching at a final pressure of 45-50 MPa at different ascent rates $(0.25$

1573 to $1.5 \mathrm{~m} / \mathrm{s}$ ). Losange symbols are experiments quenched at $25 \mathrm{MPa}$ final pressure. The 1574 correspondence between starting and final conditions is color coded (i.e. grey circles correspond 1575 to grey squares). The arrowed thin dashed lines are the equilibrium melt volatile contents 1576 calculated for each starting composition, using Papale et al. (2006)'s model. Such calculated paths 1577 are typically near vertical for the high-pressure part of the decompression interval, reflecting the 1578 preferential loss of $\mathrm{CO}_{2}$, owing to its much lower solubility compared to $\mathrm{H}_{2} \mathrm{O}$, the latter remaining 1579 dissolved for the most part. It is only close to the surface that $\mathrm{H}_{2} \mathrm{O}$ is lost. The experiments show, 1580 however, that in out-of equilibrium experiments, quenched glasses preserve a high pressure 1581 signature of $\mathrm{CO}_{2}$, whose intensity depends on the ascent rate. Supersaturation in $\mathrm{CO}_{2}$ arising from 1582 decompression may thus give rise to patterns resembling those produced by $\mathrm{CO}_{2}$-gas fluxing at 1583 depth. 

1587 the basis for the reconstruction of the reference eruption scenarios. The table shows the range of 1588 compositional and physical parameters which characterized the explosive activity at Somma1589 Vesuvius and that have been used to characterize six different eruptive styles which represent the 1590 reference eruption scenarios for hazard assessment and emergency planning. 


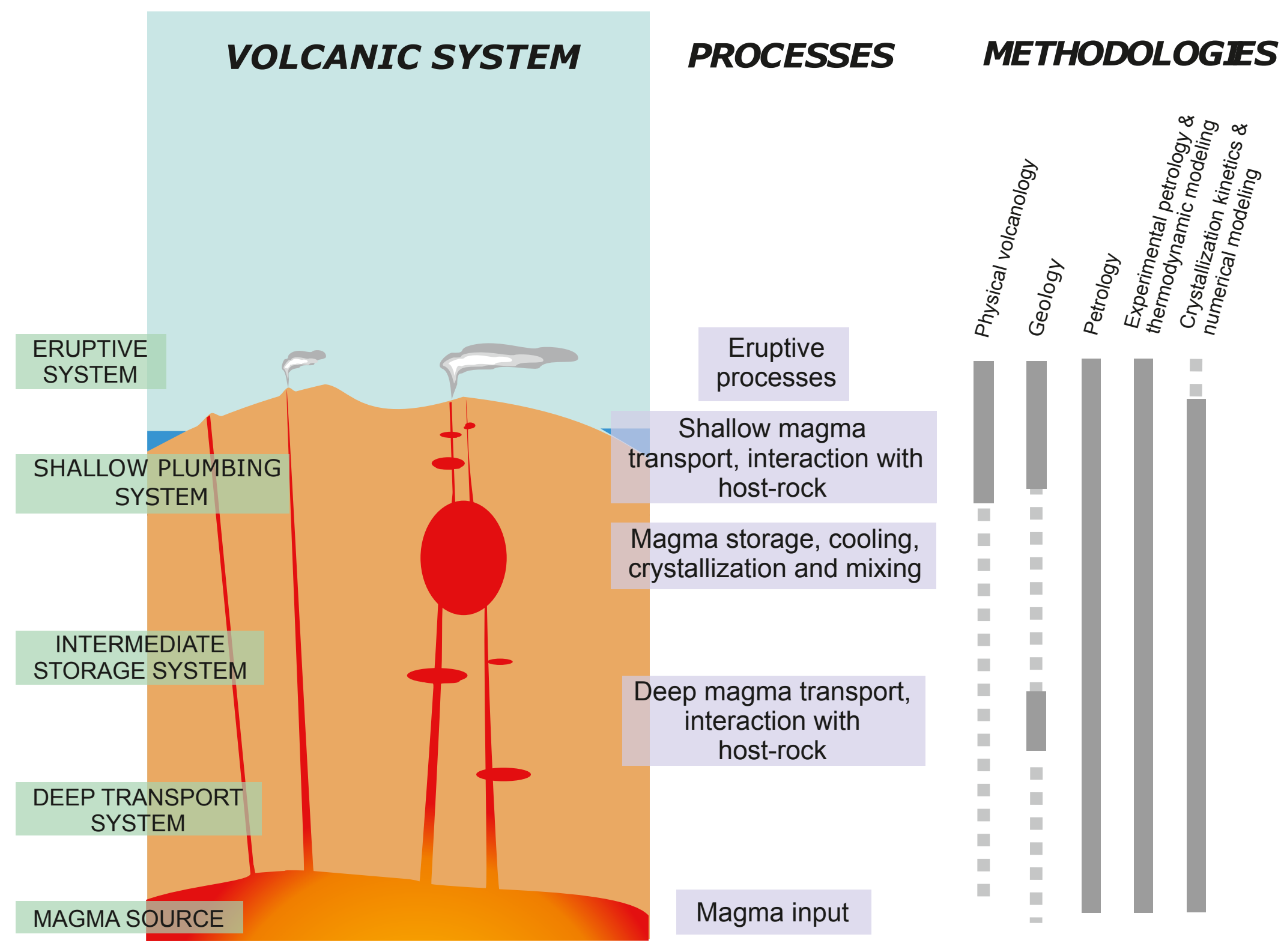



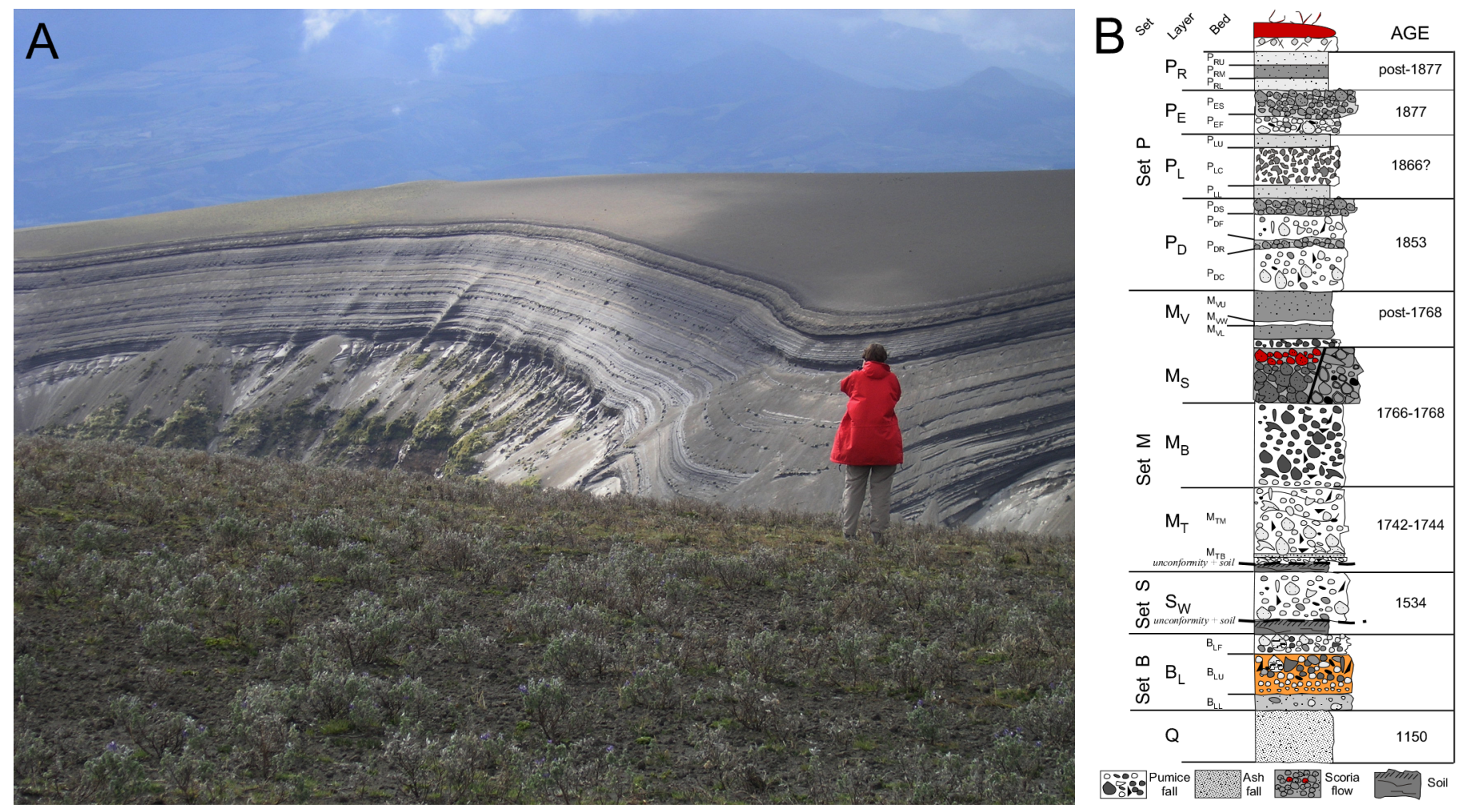

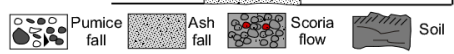



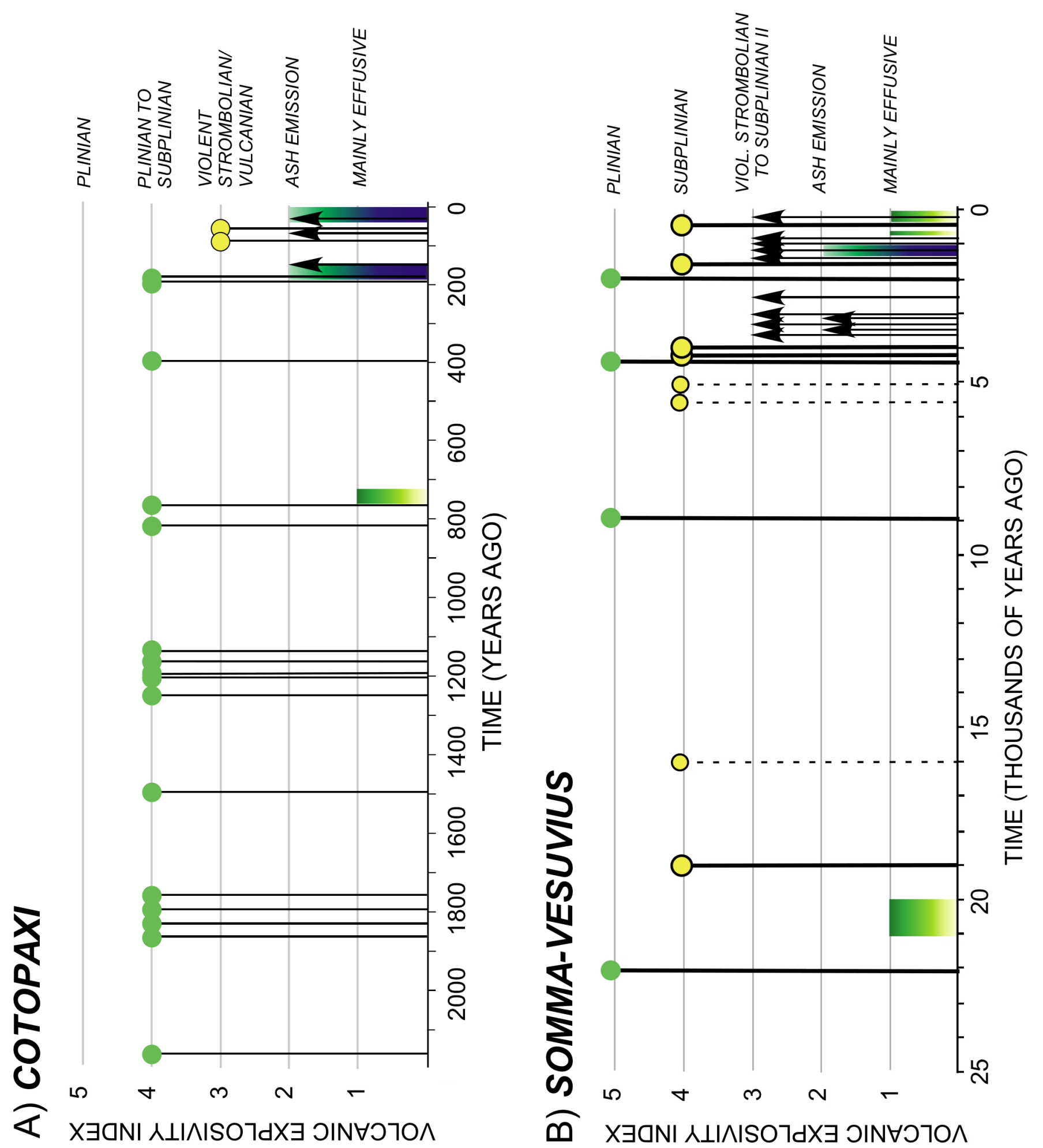


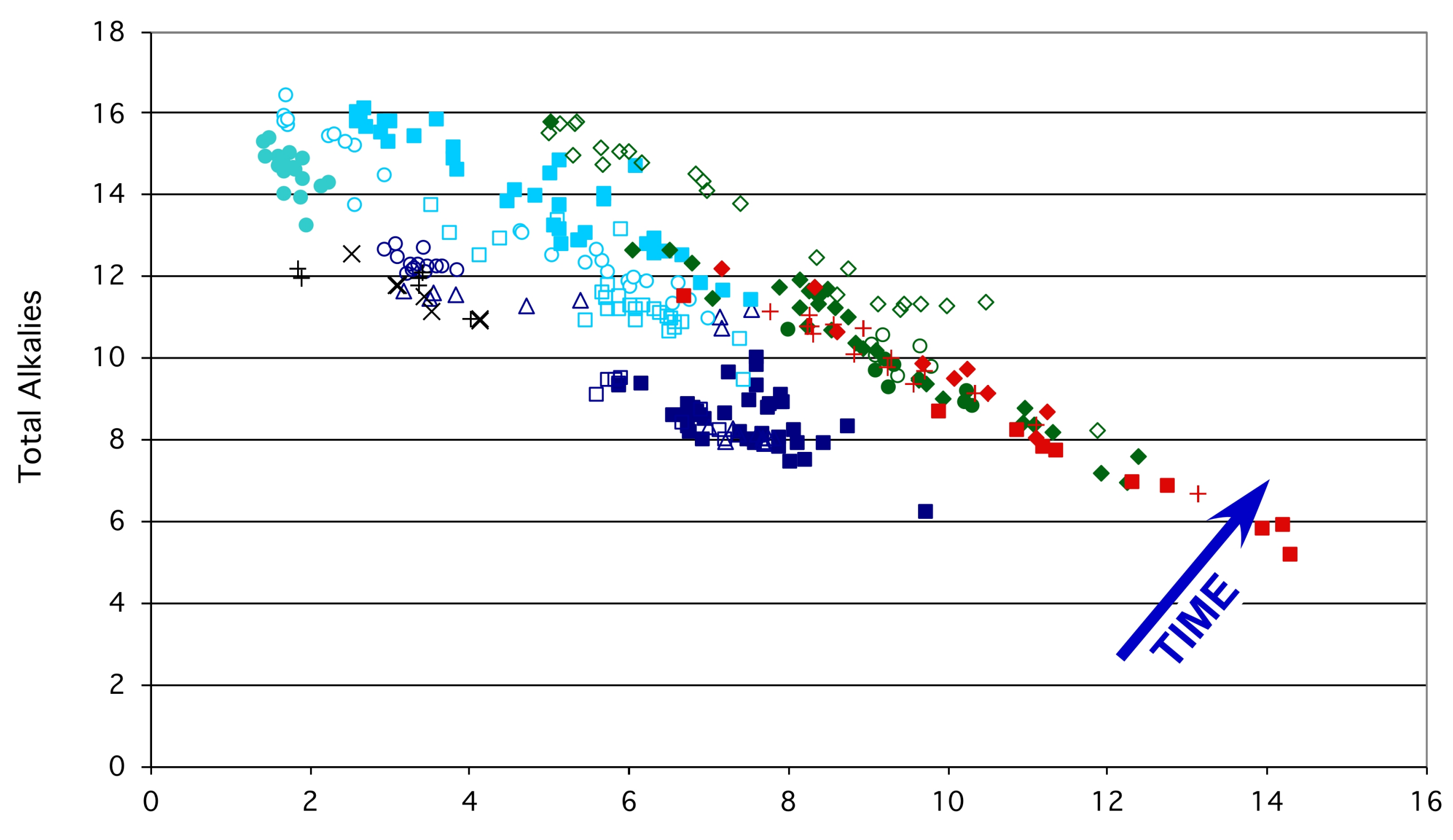

$\mathrm{CaO}$ wt\%
- Mt. Somma (39 ka - 22 ka)

$\Delta$ Pomici di Base (22 ka)

$\square$ Lateral activity

o Greenish Pumice (19 ka)

+VM eruptions

- Mercato Pumice (8.9 ka)

XMA eruptions

○ Avellino Pumice (4.4 ka)

$\square$ AP eruptions

AD 79 Pompeii

o S.Maria eruptions

$\diamond$ AD 472 Pollena

- AD 512-1000 eruptions

- Middle Age eruptions

- AD 1631 eruption

+AD 1639-1906 eruptions

1944 eruption 


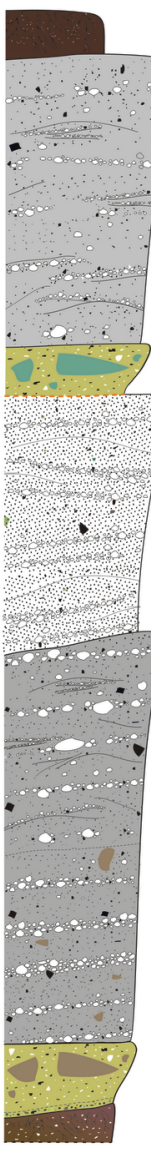

Soil (top)

Samples

$\operatorname{Md} \Phi$

Density Vesicularity VND

$\mathrm{dP} / \mathrm{dt} \quad \mathrm{SiO}_{2}$

$\mathrm{CaO} \quad \mathrm{K}_{2} \mathrm{O}$

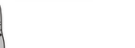

\section{PDCs and}

ballistic showers

of obsidian bombs

(Unit V)

Opening breccia (Unit IV) the two sequences

PDC-dominated

(Unit III)

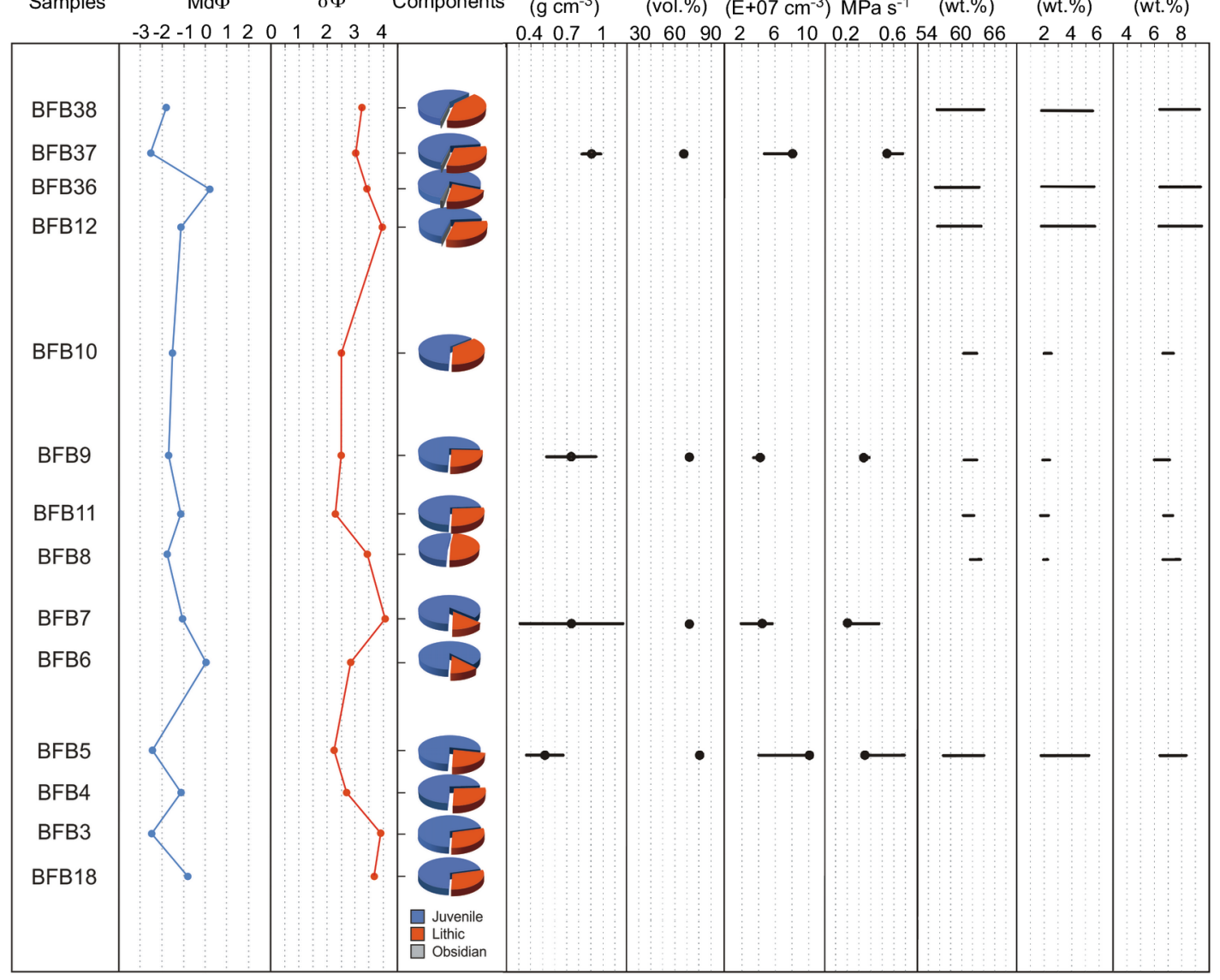

Paleosoil (base)

Fallout-dominated (Unit II)

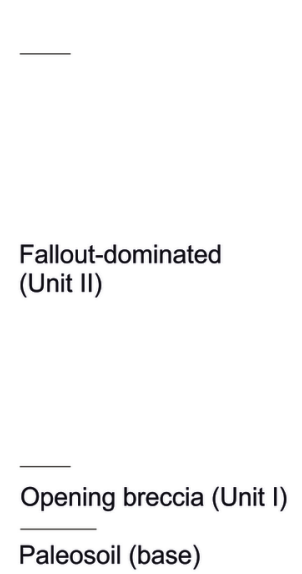




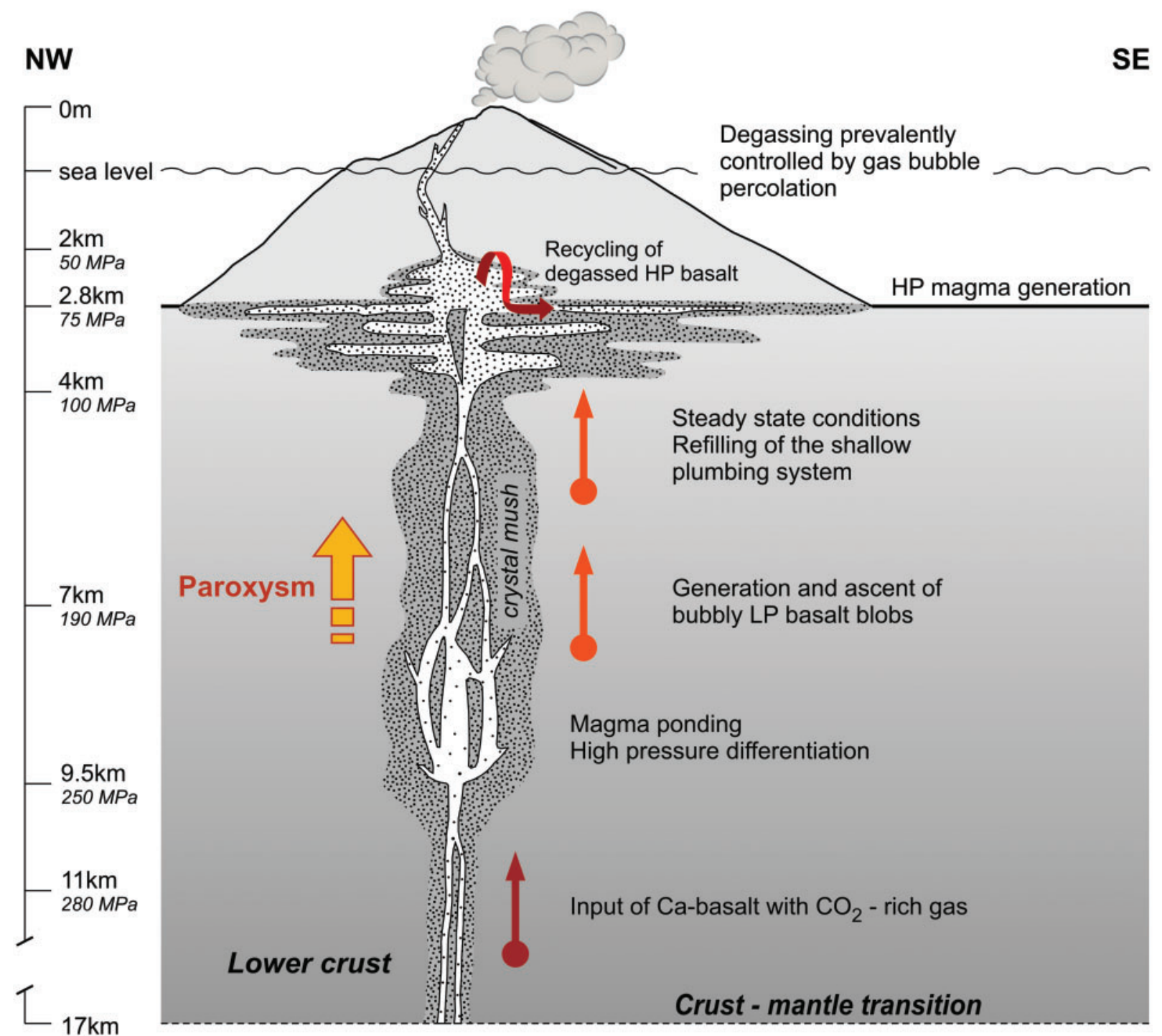

Fig. 10. Interpretative model of the plumbing system of Stromboli based on (1) the melt compositions and melt saturation pressures recorded by sealed melt inclusions and unsealed embayments trapped during olivine crystallization, (2) the crystal textures and (3) the chemistry of Stromboli pumice and scoria samples. The fluid saturation pressures are calculated using Papale et al. (2006) and the corresponding lithostatic depth assuming an average density of the surrounding rocks of $2700 \mathrm{~kg} / \mathrm{m}^{3}$. The geometry of the conduits within the uppermost $1 \mathrm{~km}-\mathrm{imaged}$ as two complex dike systems underlying the summit craters with a sharp change in fracture dip at 80 and $280 \mathrm{~m}$, respectively, below sea level (Chouet et al., 2008) - is oversimplified. LP and HP basalts refer to low- and high-porphyritic magmas, respectively, according to Francalanci et al. (2004). 
a

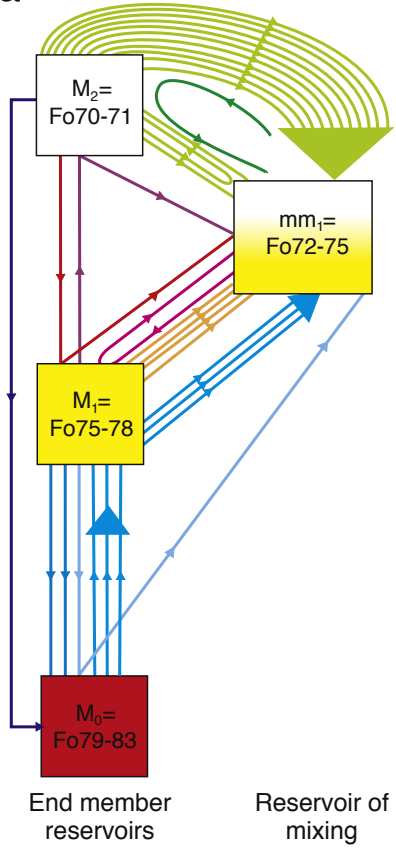

b

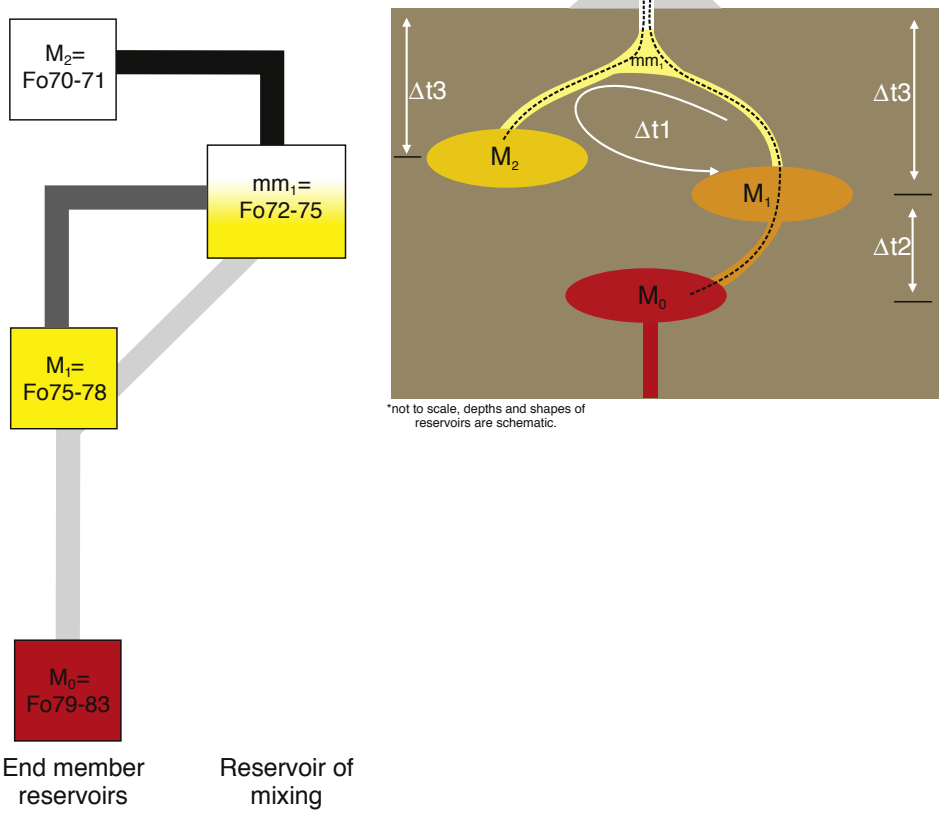

Fig. 4. The plumbing system: (a) Simplified systems analysis of the zoning patterns recorded in olivine crystals erupted between December 1991 and March 1992 . Each box represents a magmatic reservoir of different composition identified by the overall core plateau compositions and zoning patterns. $M_{0}$, $M_{1}$ and $M_{2}$ represent end member reservoirs ( $\mathrm{M}_{0}=$ Fo79-83, $\mathrm{M}_{1}=$ Fo75-78 and $\mathrm{M}_{2}=$ Fo70-71), whereas $\mathrm{mm}_{1}$ is a reservoir of mixing. The colored lines represent the zoning patterns recorded in single olivine crystals. The arrows indicate the direction of the zonings from core to rim. All reservoirs are connected with each other. The density of the connection lines can be used to infer the dominant passageways of magma transport. (b) Information distilled from (a) to highlight the three main magma pathways $\mathrm{M}_{0}-\mathrm{M}_{1}-\mathrm{mm}_{1}$ (light gray bar) $\mathrm{M}_{1}-\mathrm{mm}_{1}$ (dark gray bar) and $\mathrm{M}_{2}-$ $\mathrm{mm}_{1}$ (black bar). (c) An example of a physical plumbing system that is consistent with (a) and (b). Other possibilities exist. Locations and connectivity of reservoirs are time integrated, at any given time one or more of these may not have existed. Black dotted lines mark the preferred path followed by many crystals. Various timescales ( $\Delta \mathrm{t}_{1}, \Delta \mathrm{t}_{2}$ and $\Delta \mathrm{t}_{3}$ ) that can be extracted from kinetic modeling relate to duration of residence of melts in different segments of the plumbing system, as shown here. 

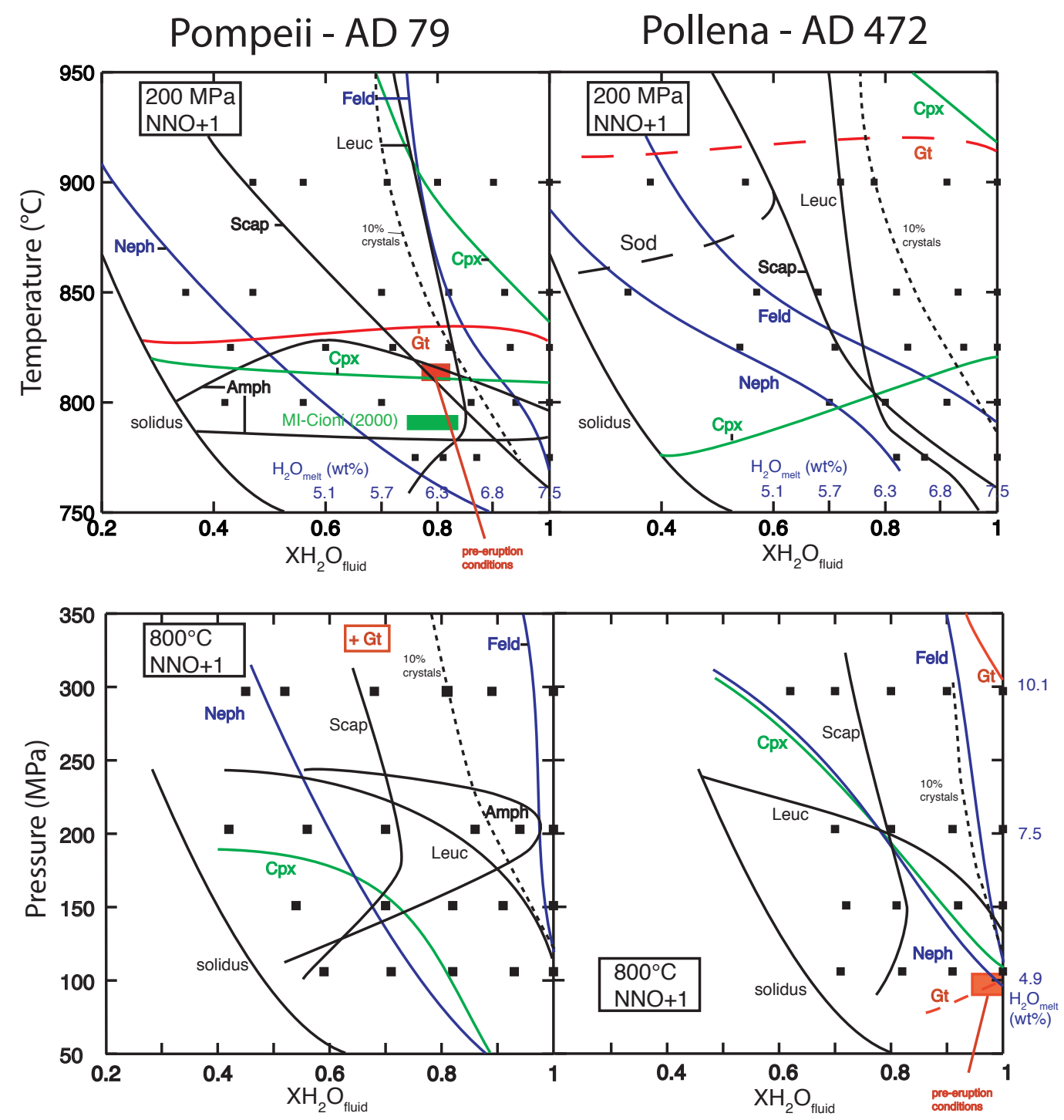

Figure 7. 

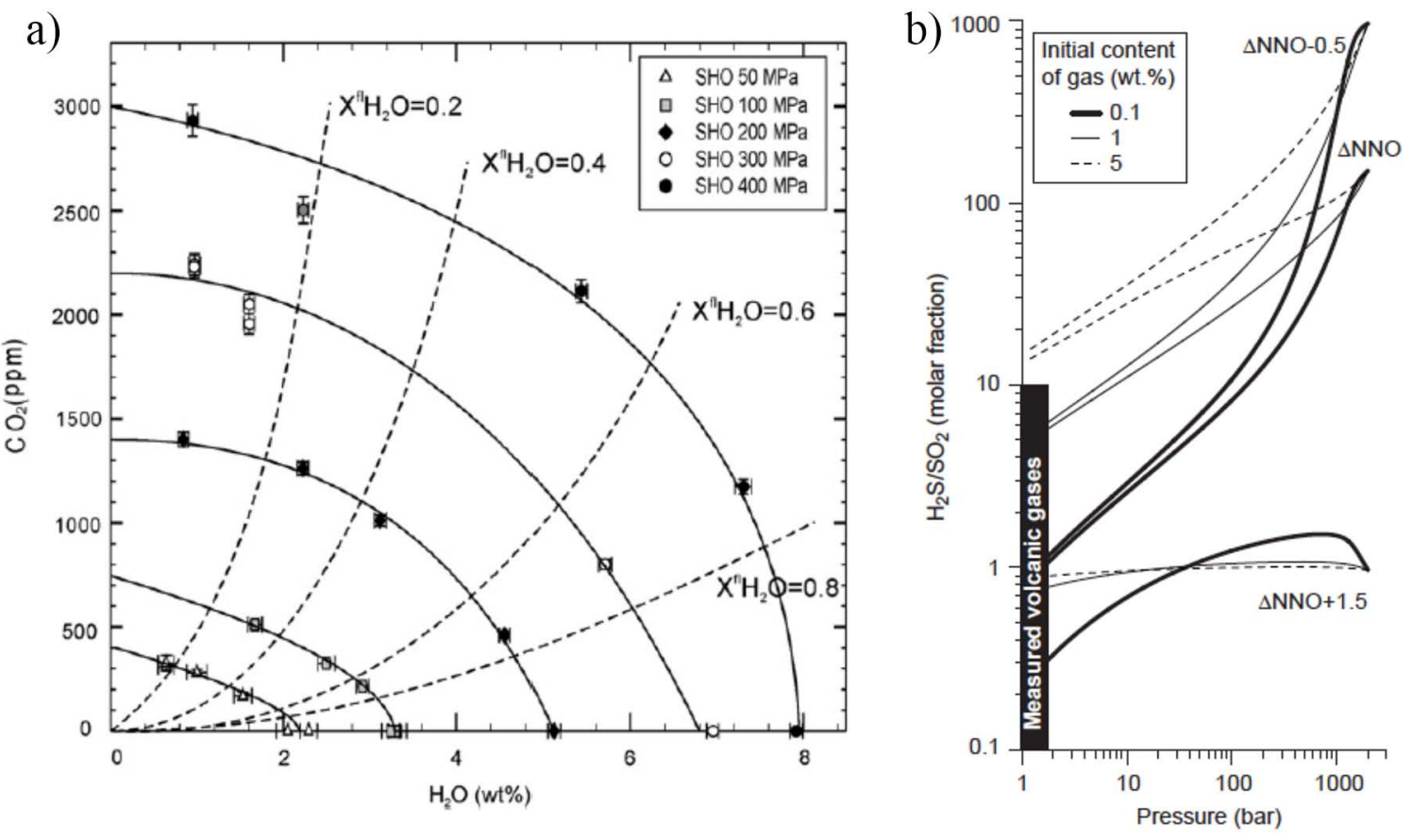

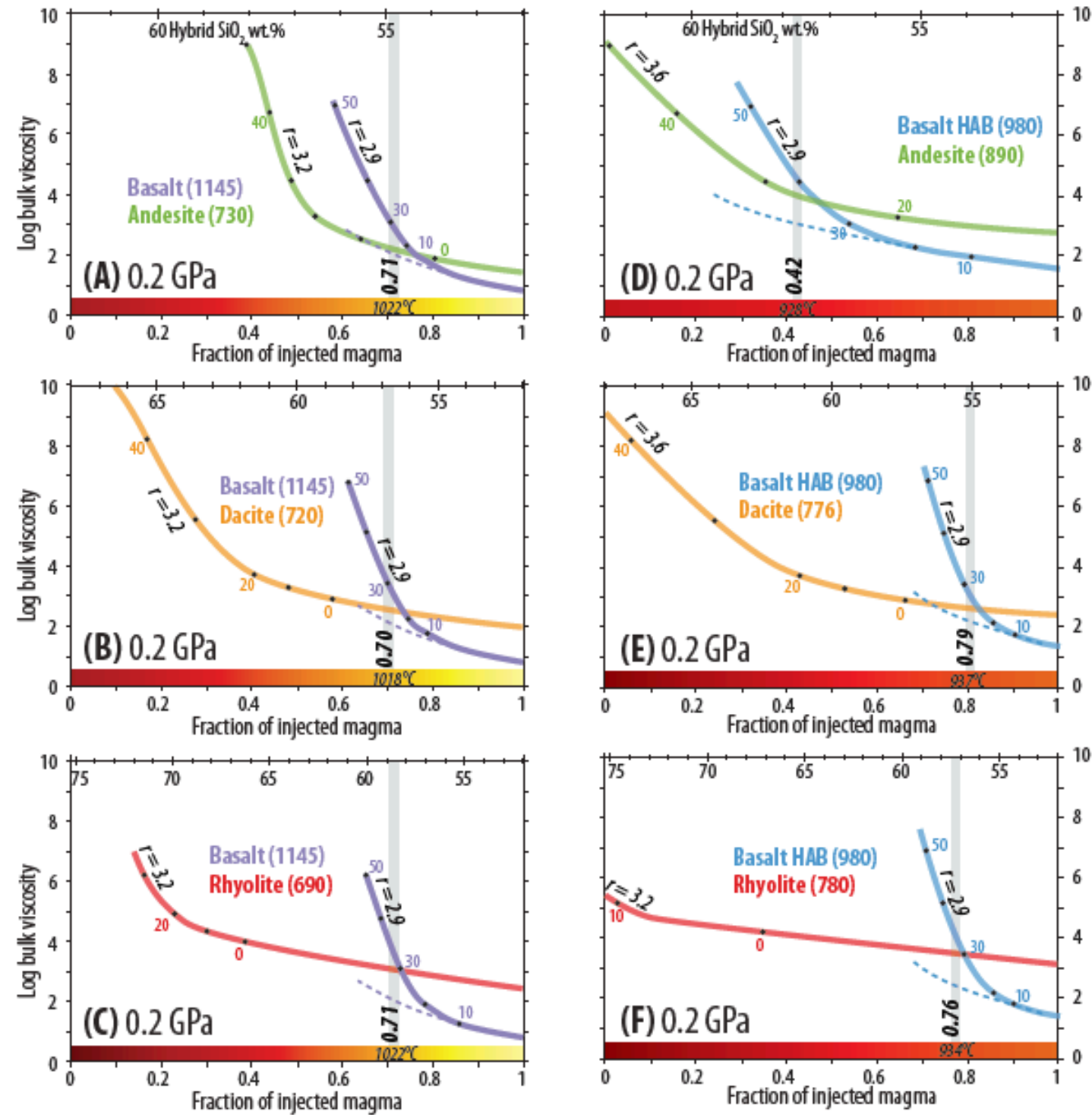
A) No mixing

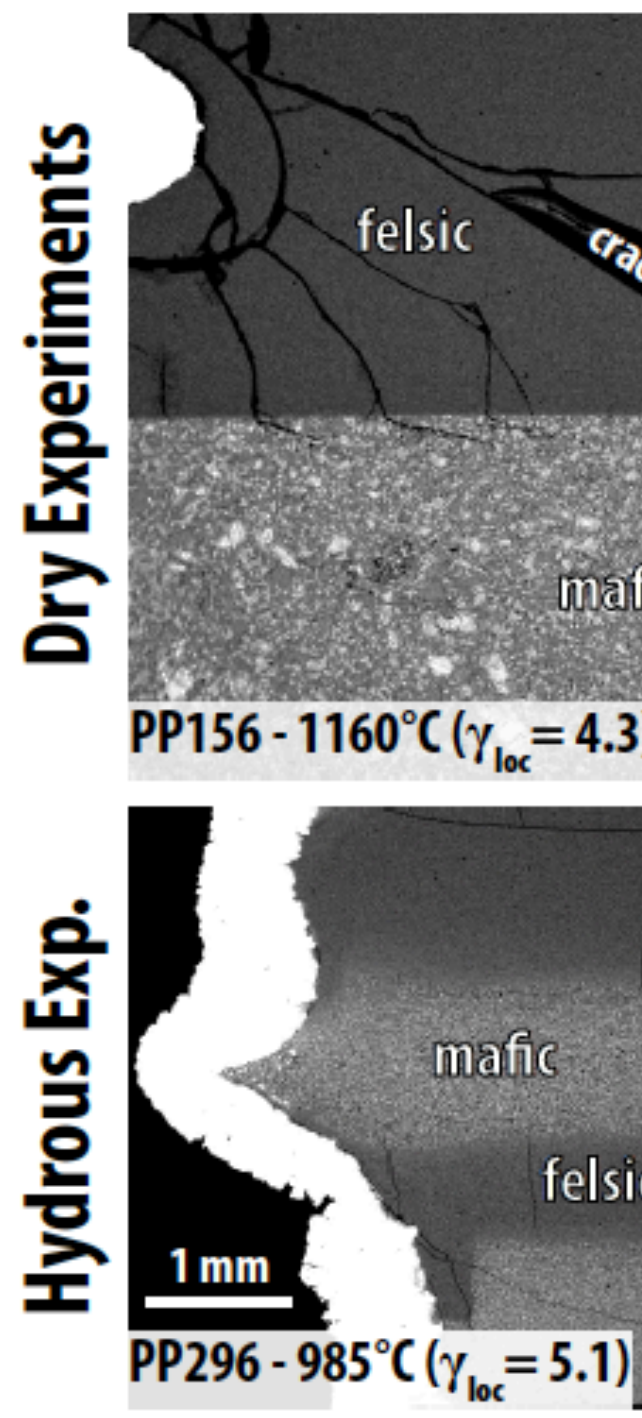

felsic
B) Mixing
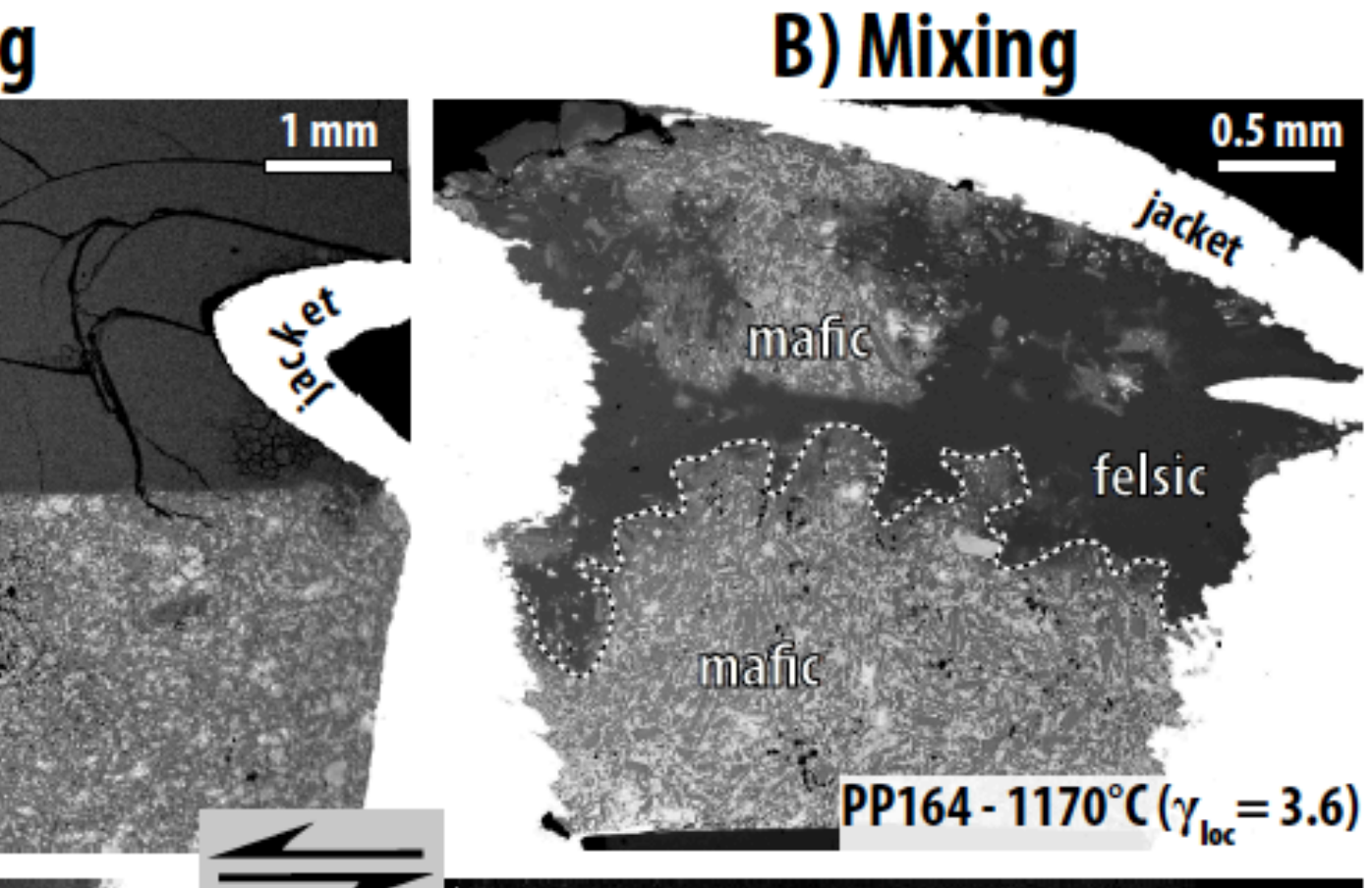
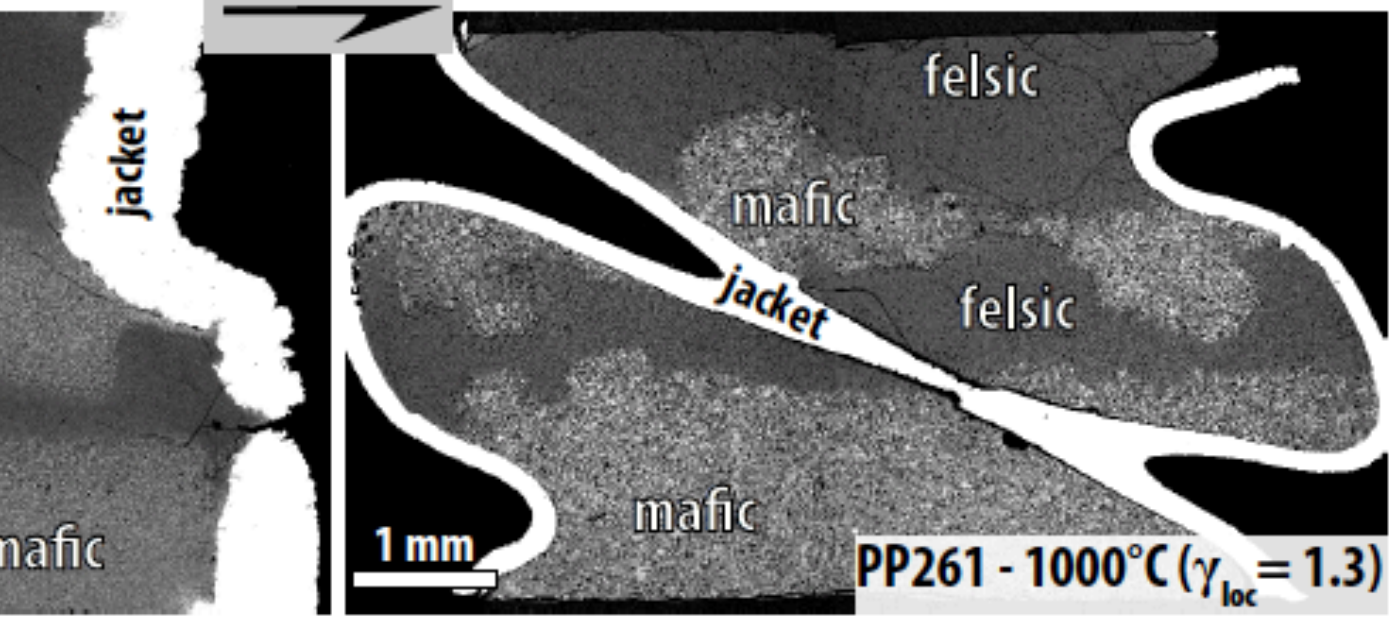


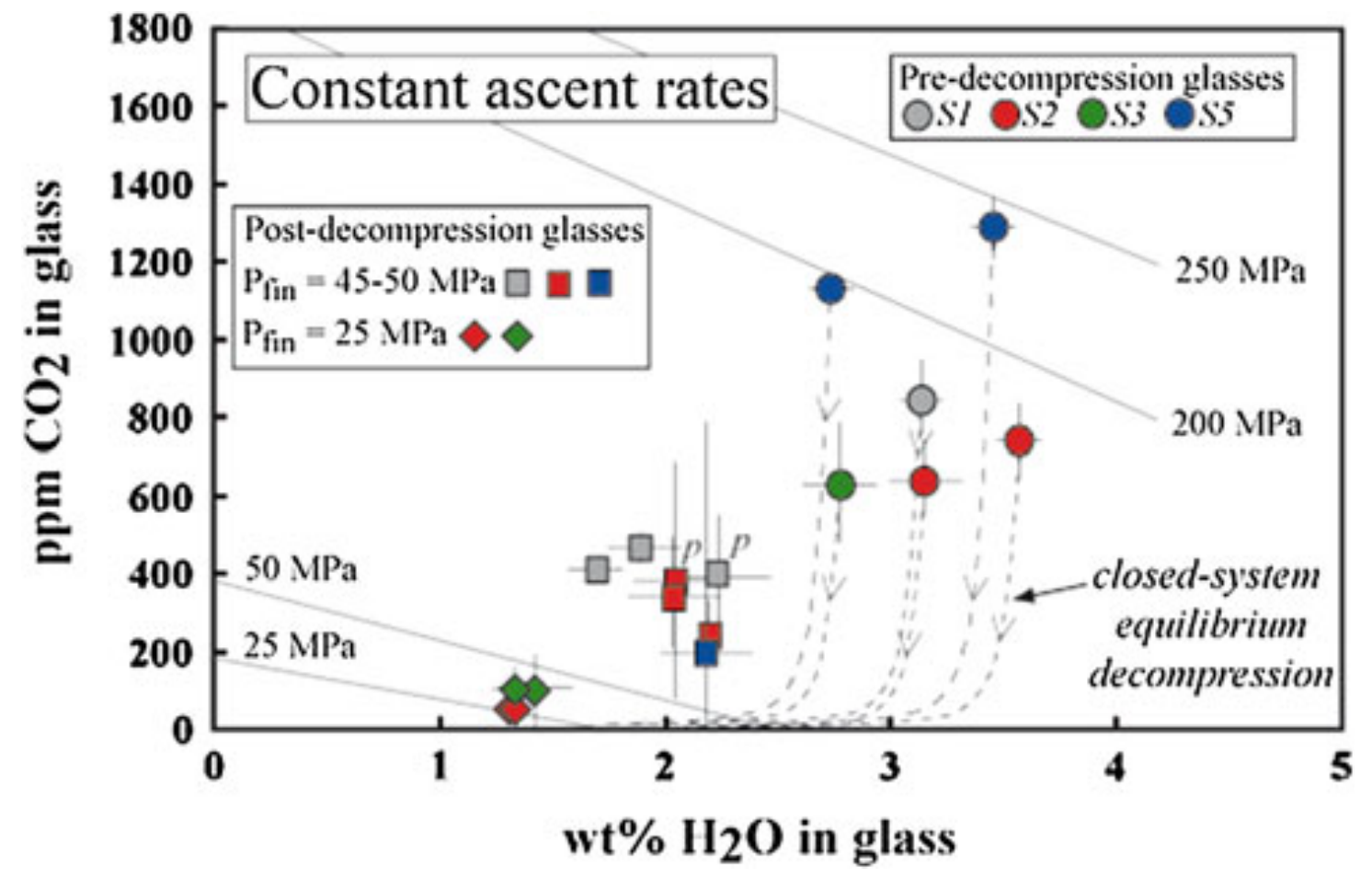




\begin{tabular}{|c|c|c|c|c|c|c|c|c|c|c|}
\hline Eruption style & $\begin{array}{c}\text { Repose } \\
\text { years }\end{array}$ & $\begin{array}{c}\text { Volume } \\
\mathrm{Km}^{3}\end{array}$ & $\begin{array}{l}\text { Peak MDR } \\
\qquad \mathrm{Kg} \mathrm{s}^{-1}\end{array}$ & $\begin{array}{l}\text { Plume } \\
\text { height } \\
\text { Km }\end{array}$ & $P D C$ & Composition & $\begin{array}{l}\mathrm{SiO}_{2} \\
w t \%\end{array}$ & $\begin{array}{c}\text { Alkali } \\
\text { wt\% }\end{array}$ & $\begin{array}{l}\mathrm{H} 2 \mathrm{O} \\
\mathrm{wt} \%\end{array}$ & $\begin{array}{l}\mathrm{CO} 2 \\
\mathrm{ppm}\end{array}$ \\
\hline $\begin{array}{l}\text { Plinian } \\
A D 79,4400 \text { BP ...... }\end{array}$ & $10^{2}-10^{3}$ & $10^{0}-10^{1}$ & $10^{7}-10^{8}$ & $>20$ & Yes & $\begin{array}{c}\text { (Trachyte) } \\
\text { Phonolite to } \\
\text { Teph.-Phonolite }\end{array}$ & $\begin{array}{l}54-61 \\
54-62\end{array}$ & $\begin{array}{l}8-12.5 \\
11-16\end{array}$ & $\begin{array}{l}5-6(4400 \\
\text { BP) } \\
6(A D 79)\end{array}$ & $\begin{array}{c}0-2000 \\
\text { bdl }\end{array}$ \\
\hline $\begin{array}{l}\text { Sub-Plinian I } \\
\text { AD 472, } 1631 \ldots .\end{array}$ & $10^{2}$ & $10^{-1}-10^{0}$ & $10^{7}$ & $15-20$ & Yes & $\begin{array}{c}\text { (Trachyte) } \\
\text { Teph.-Phonolite } \\
\text { to P-Tephrite }\end{array}$ & $\begin{array}{l}58-60 \\
48-52\end{array}$ & $\begin{array}{c}11-16 \\
(8-12 \\
\text { AD1631) }\end{array}$ & $\begin{array}{l}2.5 \text { (salic) } \\
<5 \text { (mafic) }\end{array}$ & $\begin{array}{c}0-200 \\
2000\end{array}$ \\
\hline $\begin{array}{l}\text { Sub-Plinian II } \\
\text { AP1, AP2, AD } 512 \ldots\end{array}$ & $10^{2}$ & $10^{-2}-10^{-1}$ & $10^{6}-10^{7}$ & $10-15$ & Minor & $\begin{array}{c}\text { Teph- Phonolite } \\
\text { to } \\
\text { Phon.-Tephrite }\end{array}$ & $48-54$ & $8-11$ & No data & No data \\
\hline $\begin{array}{l}\text { Viol. Strombolian } \\
\text { 1906, } 1944 \ldots .\end{array}$ & $10^{1}-10^{2}$ & $10^{-3}-10^{-1}$ & $10^{5}-10^{6}$ & $5-10$ & $\begin{array}{c}\text { Minor } \\
\text { Avalanching }\end{array}$ & $\begin{array}{c}\text { Tephrite } \\
\text { to } \\
\text { Phon.- Tephrite }\end{array}$ & $48-52$ & $6-12$ & $2-4$ & $0-2000$ \\
\hline $\begin{array}{l}\text { Ash emission events } \\
\text { AD } 79-472 \text { period, ... }\end{array}$ & $10^{1}-10^{2}$ & $\begin{array}{l}\text { Up to } 10^{-2} \\
\text { (cumulativ } \\
\text { e) }\end{array}$ & $\begin{array}{c}10^{5} \text { (Viol Stromb. } \\
\text { Phases) } \\
10^{3} \text { (Average) }\end{array}$ & $<5$ & No & $\begin{array}{l}\text { Teph-Phonolite } \\
\text { to } \\
\text { Phon-Tephrite }\end{array}$ & $49-51$ & $9-12$ & $1-2$ & $0-1000$ \\
\hline $\begin{array}{l}\text { Mild strombolian } \\
\text { Post } 1631 \text { period, ... }\end{array}$ & $10^{0}-10^{1}$ & $10^{-3}$ & & $\begin{array}{l}\text { No } \\
\text { convective } \\
\text { plume }\end{array}$ & No & $\begin{array}{c}\text { Tephrite } \\
\text { to } \\
\text { Phon.- Tephrite }\end{array}$ & $47-49$ & $7-11$ & No data & No data \\
\hline
\end{tabular}

